\title{
Silicon Amendment Enhances Agronomic Efficiency of Nitrogen Fertilization in Maize and Wheat Crops under Tropical Conditions
}

\author{
Fernando Shintate Galindo 1,*(D), Paulo Humberto Pagliari ${ }^{2}{ }^{(}$, Willian Lima Rodrigues ${ }^{3}$, \\ Guilherme Carlos Fernandes ${ }^{3}$, Eduardo Henrique Marcandalli Boleta ${ }^{3}$, José Mateus Kondo Santini ${ }^{3}$, \\ Arshad Jalal $^{3}{ }^{(0)}$, Salatiér Buzetti ${ }^{3}$, José Lavres ${ }^{3}\left(\mathbb{B}\right.$ and Marcelo Carvalho Minhoto Teixeira Filho ${ }^{3}$ (D)
}

check for

updates

Citation: Galindo, F.S.; Pagliari, P.H.; Rodrigues, W.L.; Fernandes, G.C.; Boleta, E.H.M.; Santini, J.M.K.; Jalal, A.; Buzetti, S.; Lavres, J.; Teixeira Filho, M.C.M. Silicon Amendment Enhances Agronomic Efficiency of Nitrogen Fertilization in Maize and Wheat Crops under Tropical Conditions. Plants 2021, 10, 1329. https://doi.org/10.3390/ plants10071329

Academic Editors: Seyed

Abdollah Hosseini,

Benjamin Pommerrenig and Nusrat Ali

Received: 1 June 2021

Accepted: 26 June 2021

Published: 29 June 2021

Publisher's Note: MDPI stays neutral with regard to jurisdictional claims in published maps and institutional affiliations.

Copyright: (C) 2021 by the authors. Licensee MDPI, Basel, Switzerland. This article is an open access article distributed under the terms and conditions of the Creative Commons Attribution (CC BY) license (https:/ / creativecommons.org/licenses/by/ $4.0 /$ )
1 Center for Nuclear Energy in Agriculture (CENA), University of São Paulo (USP), Piracicaba 13416-000, Brazil 2 Department of Soil, Water, and Climate, Southwest Research and Outreach Center (SWROC), University of Minnesota (UMN), Lamberton, MN 56152, USA; pagli005@umn.edu

3 Department of Plant Health, Rural Engineering, and Soils (DEFERS), São Paulo State University (UNESP), Ilha Solteira 15345-000, Brazil; willianrodrigues53@gmail.com (W.L.R.); guilherme.carlos.fernandes@gmail.com (G.C.F.); eduardomarcandalli7@gmail.com (E.H.M.B.); santinijmk@gmail.com (J.M.K.S.); arshad.jalal@unesp.br (A.J.); sbuzetti@agr.feis.unesp.br (S.B.); jlavres@usp.br (J.L.); mcm.teixeira-filho@unesp.br (M.C.M.T.F.)

* Correspondence: fsgalindo@usp.br

\begin{abstract}
Sustainable management strategies are needed to improve agronomic efficiency and cereal yield production under harsh abiotic climatic conditions such as in tropical Savannah. Under these environments, field-grown crops are usually exposed to drought and high temperature conditions. Silicon ( $\mathrm{Si}$ ) application could be a useful and sustainable strategy to enhance agronomic $\mathrm{N}$ use efficiency, leading to better cereal development. This study was developed to explore the effect of $\mathrm{Si}$ application as a soil amendment source ( $\mathrm{Ca}$ and $\mathrm{Mg}$ silicate) associated with $\mathrm{N}$ levels applied in a side-dressing (control, low, medium and high $\mathrm{N}$ levels) on maize and wheat development, $\mathrm{N}$ uptake, agronomic efficiency and grain yield. The field experiments were carried out during four cropping seasons, using two soil amendment sources ( $\mathrm{Ca}$ and $\mathrm{Mg}$ silicate and dolomitic limestone) and four $\mathrm{N}$ levels $\left(0,50,100\right.$ and $\left.200 \mathrm{~kg} \mathrm{~N} \mathrm{ha}^{-1}\right)$. The following evaluations were performed in maize and wheat crops: the shoots and roots biomass, total $\mathrm{N}, \mathrm{N}-\mathrm{NO}_{3}{ }^{-}, \mathrm{N}-\mathrm{NH}_{4}{ }^{+}$and $\mathrm{Si}$ accumulation in the shoots, roots and grain tissue, leaf chlorophyll index, grain yield and agronomic efficiency. The silicon amendment application enhanced leaf chlorophyll index, agronomic efficiency and N-uptake in maize and wheat plants, benefiting shoots and roots development and leading to a higher grain yield (an increase of 5.2 and $7.6 \%$, respectively). It would be possible to reduce $\mathrm{N}$ fertilization in maize from 185-180 to $100 \mathrm{~kg} \mathrm{~N}^{-1}$ while maintaining similar grain yield with Si application. Additionally, Si application would reduce $\mathrm{N}$ fertilization in wheat from 195-200 to $100 \mathrm{~kg} \mathrm{~N} \mathrm{ha}^{-1}$. Silicon application could be a key technology for improving plant-soil N-management, especially in $\mathrm{Si}$ accumulator crops, leading to a more sustainable cereal production under tropical conditions.
\end{abstract}

Keywords: Silicon application; sustainable crop production; tropical agriculture; Ca and Mg silicate; improved nitrogen management

\section{Introduction}

Silicon ( $\mathrm{Si}$ ) is the second most abundant element after oxygen in the Earth's crust, comprising approximately $29 \%(28.8 \% \mathrm{wt})$ of the Earth's crust [1-3]. Although Si is considered a quasi-essential element rather than a plant nutrient, it is increasingly being applied in agricultural systems worldwide [2-5]. Silicon content in the soil ranges from almost 1 to $45 \%$ depending on soil types [6]. The potential of Si in improving crop yield has been demonstrated in many studies, especially under biotic (pathogens attack) and abiotic (e.g., salinity, drought, high temperature, heavy metals toxicity) stress conditions $[7,8]$. 
Silicon is known for its role in alleviating negative effects of stress on many plant species. Monocotyledons in general and Poaceae species such as maize (Zea mays L.) and wheat (Triticum aestivum L.) are clearly favored due to an enhanced supply of Si $[3,6,9]$. It has been reported that some Poaceae species could accumulate Si to a level above $1 \%$ of total shoot biomass [7].

The cultivation and harvest of Si-accumulating crops is responsible for a constant depletion of the Si reservoir in soils [10,11] which may decrease Si bioavailability [12]. The enhanced Si removal by Si-accumulating crops, therefore, disrupts the recycling of Si by plants back into the soil [13]. Liang et al. [14] reported that Si content in Oxisols in the tropical zone can be less than $1 \%$ due to intense weathering processes. Highly weathered tropical and subtropical soils under continuous cropping systems are generally low in available Si content due to heavy desilication of primary silicate minerals, release and leaching of basic cations with decreased base saturation, and crop removal $[3,7,15,16]$. Therefore, the decrease in Si availability in tropical soils might have significant impacts on cropping systems if not properly managed.

A further problem in weathered and acidic soils is related to the occurrence of high levels of exchangeable $\mathrm{Al}^{3+}$. Soil acidity and related $\mathrm{Al}^{3+}$ toxicity have long been recognized as significant and alarming constraints in cereal production under tropical conditions. Nonetheless, $\mathrm{Ca}$ and $\mathrm{Mg}$ silicate could be a viable alternative to increase Si availability and neutralize $\mathrm{Al}$ toxicity as an alternative to conventional liming. Silicate application could reduce the time associated with liming reactions in the soil profile due to their higher solubility (6-7 times more soluble than carbonates) and alkalinity compared with limestone $[17,18]$. However, most studies related to Si-amendment sources application focused on soil chemical shifts instead of plant growth promotion, and nutrient uptake and imbalance. The application of various forms of Si (i.e., slag materials, silica powder, silicates, among others) could improve plant growth and development with greater nutrient uptake in different crops [16,19-21]. Haddad et al. [22] indicated a beneficial effect of Si treatment in alleviating damage associated with nitrogen $(\mathrm{N})$ deficiency in rapeseed (Brassica napus $\mathrm{L}$.). These authors showed that $\mathrm{Si}$ supply modulates the root expression of a large panel of genes [23], promotes a stronger $\mathrm{N}$ uptake associated with the induction of root nitrate transporters, and delays leaf senescence in plants cultivated under $\mathrm{N}$ deficiency [22]. Nonetheless, Si application has been reported to increase $\mathrm{N}$ availability in the soil by modifying physicochemical (e.g., soil exchange capacity) $[24,25]$ and biological properties of soil (e.g., increasing the biomass of microbial N fixers) [26]. Singh et al. [27] reported that $\mathrm{Si}$ application in rice (Oryza sativa L.) enhances $\mathrm{N}$ availability in soil and leads to an increase in $\mathrm{N}$ uptake by plants. Laîné et al. [28] concluded that Si application (12 $\mathrm{kg} \mathrm{Si} \mathrm{ha}^{-1}$ as silicic acid) may have increased $\mathrm{N}$ availability in the soil, improved $\mathrm{N}$ uptake, and led to an accumulation of $\mathrm{N}$ in rapeseed plants cultivated with high $\mathrm{N}$ rates $\left(160 \mathrm{~kg} \mathrm{ha}^{-1}\right)$. In this regard, $\mathrm{Si}$ application could affect $\mathrm{N}$ availability to plants and enhance nutrient use efficiency (also known as agronomic efficiency), expressed as grain produced per unit of $\mathrm{N}$ applied. Thereby, Si fertilization might improve $\mathrm{N}$ fertilization management while reducing the need for mineral $\mathrm{N}$ fertilization in agricultural systems [19].

Nitrogen is considered one of the most limiting nutrients for crop growth and yield [29]. However, excessive $\mathrm{N}$ supply could directly contribute to soil acidification, ammonia $\left(\mathrm{NH}_{3}\right)$ and nitrogen oxide $\left(\mathrm{N}_{2} \mathrm{O}, \mathrm{NO}_{2}\right.$ and $\left.\mathrm{NO}\right)$ emissions, and $\mathrm{N}$ leaching with extended consequences on global warming [30]. The application of $\mathrm{N}$ to maize and wheat using a side-dressing approach in the Brazilian Savannah has led to an increase of about $15 \%$ in the farmer's total operational profit [31,32]. Over the last decades, several management practices have been developed to enable farmers to reduce the application of N-based fertilizers in cereal crops in order to limit potential negative environmental impacts and cost resulting from the heavy application of chemical $\mathrm{N}$ fertilizer [33]. Integrating $\mathrm{N}$ management practices could contribute significantly to improved cereal production under the savannah conditions, particularly in a maize-wheat rotation, which has high $\mathrm{N}$ nutritional demands [34,35]. Moreover, developing management practices that enhance agronomic 
efficiency leading to a greater grain yield is required to foment sustainable agricultural practices in the tropical agriculture.

Therefore, we propose a novel approach to investigate the effect of Si-amendment application, combined with $\mathrm{N}$ levels in a maize-wheat cropping system under tropical conditions. This research could provide new clues on how Si application could be included as an important strategy for improving the sustainability of cereal production with an improved $\mathrm{N}$ fertilization management. We hypothesized that $\mathrm{Si}$ application would improve the agronomic efficiency and $\mathrm{N}$ accumulation in maize and wheat crops. The increased agronomic efficiency and $\mathrm{N}$ accumulation may provide increased shoot and root development which may lead to greater grain yield when compared to plots that did not receive $\mathrm{Si}$ application. Therefore, the objective of this study was to investigate the combined effects of Si-amendment source ( $\mathrm{Ca}$ and $\mathrm{Mg}$ silicate) and $\mathrm{N}$ levels (control, low, medium and high levels) application on: (1) leaf chlorophyll index (LCI), inorganic $\left(\mathrm{N}_{-} \mathrm{NH}_{4}{ }^{+}\right.$and $\mathrm{N}^{-\mathrm{NO}_{3}}{ }^{-}$) and total $\mathrm{N}$ and $\mathrm{Si}$ content in maize and wheat plants; (2) plant biomass, grain yield and agronomic efficiency of individual treatments.

\section{Results}

\subsection{Summary of the Statistical Analysis: Maize}

Silicon application significantly affected $\mathrm{LCI}$, root $\mathrm{Si}$, shoot $\mathrm{N}-\mathrm{NO}_{3}{ }^{-}$, shoot $\mathrm{N}-\mathrm{NH}_{4}{ }^{+}$ and shoot $\mathrm{Si}$ accumulation, shoot biomass and grain yield (Appendix A, Table 1). Nitrogen application significantly affected $\mathrm{LCI}, \operatorname{root} \mathrm{N}$, root $\mathrm{Si}$, shoot $\mathrm{N}-\mathrm{NO}_{3}{ }^{-}$, shoot $\mathrm{N}-\mathrm{NH}_{4}{ }^{+}$and shoot $\mathrm{Si}$ accumulation, shoot biomass and grain yield (Appendix $\mathrm{A}$, Table 2). Years of study significantly affected root $\mathrm{N}^{-N_{3}}{ }^{-}$, $\operatorname{root} \mathrm{N}$, shoot $\mathrm{N}^{-\mathrm{NH}_{4}}{ }^{+}$, shoot $\mathrm{N}$ and shoot $\mathrm{Si}$ accumulation, root biomass, shoot biomass and grain yield (Appendix A, Table 3).

Table 1. Maize leaf chlorophyll index (LCI); root Si accumulation; shoot nitrate $\left(\mathrm{N}^{-} \mathrm{NO}_{3}{ }^{-}\right)$; shoot ammonium $\left(\mathrm{N}^{-\mathrm{NH}_{4}}{ }^{+}\right)$; shoot $\mathrm{Si}$ accumulation; shoot biomass and grain yield as a function of $\mathrm{Si}$ amendment application.

\begin{tabular}{|c|c|c|c|c|}
\hline Sources & LCI & Root Si & Shoot $\mathrm{N}-\mathrm{NO}_{3}{ }^{-}$ & Shoot N-NH ${ }_{4}^{+}$ \\
\hline & & $\left(\mathrm{kg} \mathrm{ha}^{-1}\right)$ & \multicolumn{2}{|c|}{$-\left(\mathrm{g} \mathrm{ha}^{-1}\right) \longrightarrow$} \\
\hline$-\mathrm{Si}$ & $65.9 \mathrm{~b} \pm 2.9$ & $7.30 b \pm 0.58$ & $2157 b \pm 187$ & $2423 b \pm 168$ \\
\hline$+\mathrm{Si}$ & $68.9 \mathrm{a} \pm 3.0$ & $9.71 \mathrm{a} \pm 0.41$ & $2408 \mathrm{a} \pm 198$ & $2715 \mathrm{a} \pm 171$ \\
\hline Sources & Shoot Si & Shoot Biomass & \multicolumn{2}{|c|}{ Grain Yield } \\
\hline \multicolumn{5}{|c|}{$\longrightarrow\left(\mathrm{kg} \mathrm{ha}^{-1}\right) \longrightarrow$} \\
\hline $\begin{array}{l}-\mathrm{Si} \\
+\mathrm{Si}\end{array}$ & $\begin{array}{l}27.2 \mathrm{~b} \pm 1.5 \\
32.2 \mathrm{a} \pm 1.8\end{array}$ & $\begin{array}{l}11713 b \pm 526 \\
12296 a \pm 539\end{array}$ & \multicolumn{2}{|c|}{$\begin{array}{c}9230 b \pm 434 \\
9711 a \pm 390\end{array}$} \\
\hline
\end{tabular}

Different letters indicate significant differences between treatments according to Tukey test $(p \leq 0.05) . \pm$ indicate standard deviations $(n=4)$. $-\mathrm{Si}$ and $+\mathrm{Si}$ refers to absence and presence of $\mathrm{Si}$ amendment application.

Table 2. Maize leaf chlorophyll index (LCI); $\operatorname{root} \mathrm{N}$; root Si accumulation; shoot nitrate $\left(\mathrm{N}_{-} \mathrm{NO}_{3}{ }^{-}\right.$); shoot ammonium $\left(\mathrm{N}-\mathrm{NH}_{4}{ }^{+}\right)$; shoot $\mathrm{Si}$ accumulation; shoot biomass and grain yield as a function of $\mathrm{N}$ levels.

\begin{tabular}{ccccc}
\hline N Rates & LCI & Root N & Root Si & Shoot N-NO $^{-}$ \\
\hline & & \multicolumn{2}{c}{$\left(\mathrm{kg} \mathrm{ha}^{-1}\right)$} & $\left(\mathrm{g} \mathrm{ha}^{-1}\right)$ \\
\hline Control (C 0N) & $63.4 \mathrm{~b} \pm 2.8$ & $4.00 \mathrm{c} \pm 0.55$ & $6.84 \mathrm{c} \pm 0.60$ & $1837 \mathrm{c} \pm 216$ \\
N Low & $67.3 \mathrm{a} \pm 2.8$ & $5.17 \mathrm{ab} \pm 0.55$ & $8.35 \mathrm{~b} \pm 0.64$ & $2262 \mathrm{~b} \pm 177$ \\
N Medium & $69.3 \mathrm{a} \pm 2.7$ & $4.89 \mathrm{~b} \pm 0.50$ & $8.33 \mathrm{~b} \pm 0.49$ & $2419 \mathrm{ab} \pm 194$ \\
N High & $69.4 \mathrm{a} \pm 3.0$ & $5.76 \mathrm{a} \pm 0.51$ & $10.47 \mathrm{a} \pm 0.68$ & $2610 \mathrm{a} \pm 247$ \\
\hline
\end{tabular}


Table 2. Cont.

\begin{tabular}{ccccc}
\hline N Rates & Shoot N-NH ${ }^{+}$ & Shoot Si & Shoot biomass & Grain yield \\
\hline & $\left(\mathrm{g} \mathrm{ha}^{-1}\right)$ & $\left(\mathrm{kg} \mathrm{ha}^{-1}\right)$ & \\
\hline Control $(\mathrm{C} \mathrm{0N})$ & $2182 \mathrm{~b} \pm 149$ & $24.6 \mathrm{~b} \pm 2.24$ & $9482 \mathrm{c} \pm 296$ & $8415 \mathrm{c} \pm 363$ \\
N Low & $2524 \mathrm{a} \pm 163$ & $31.4 \mathrm{a} \pm 2.15$ & $12077 \mathrm{~b} \pm 505$ & $9233 \mathrm{~b} \pm 358$ \\
N Medium & $2767 \mathrm{a} \pm 206$ & $31.5 \mathrm{a} \pm 1.80$ & $13181 \mathrm{a} \pm 505$ & $9913 \mathrm{a} \pm 364$ \\
N High & $2801 \mathrm{a} \pm 140$ & $31.3 \mathrm{a} \pm 2.24$ & $13277 \mathrm{a} \pm 577$ & $10320 \mathrm{a} \pm 361$
\end{tabular}

Different letters indicate significant differences between treatments according to Tukey test $(p \leq 0.05)$. \pm indicate standard deviations $(n=4)$. Ctl, Low, Med and High refers to absence, 50, 100 and $200 \mathrm{~kg} \mathrm{~N}^{-1}$ applied in $^{-1}$ side-dressing respectively.

Table 3. Maize root nitrate $\left(\mathrm{N}_{-} \mathrm{NO}_{3}{ }^{-}\right)$; root $\mathrm{N}$ accumulation; shoot ammonium $\left(\mathrm{N}_{-} \mathrm{NH}_{4}{ }^{+}\right)$; $\operatorname{shoot} \mathrm{N}$; shoot $\mathrm{Si}$ accumulation; root biomass; shoot biomass and grain yield as a function of years of study.

\begin{tabular}{|c|c|c|c|c|}
\hline Year & Root $\mathrm{N}-\mathrm{NO}_{3}{ }^{-}$ & Root N & Shoot N-NH${ }_{4}^{+}$ & Shoot N \\
\hline & $\left(\mathrm{g} \mathrm{ha}^{-1}\right)$ & $\left(\mathrm{kg} \mathrm{ha}^{-1}\right)$ & $\left(\mathrm{g} \mathrm{ha}^{-1}\right)$ & $\left(\mathrm{kg} \mathrm{ha}^{-1}\right)$ \\
\hline 1 & $357 b \pm 75$ & $4.09 \mathrm{~b} \pm 0.47$ & $2712 \mathrm{a} \pm 178$ & $316 a \pm 32$ \\
\hline 2 & $545 \mathrm{a} \pm 86$ & $5.82 \mathrm{a} \pm 0.49$ & $2424 b \pm 177$ & $208 b \pm 32$ \\
\hline \multirow[t]{2}{*}{ Year } & Shoot Si & Root Biomass & Shoot Biomass & Grain Yield \\
\hline & \multicolumn{4}{|c|}{$\left(\mathrm{kg} \mathrm{ha}^{-1}\right)$} \\
\hline 1 & $31.2 \mathrm{a} \pm 1.92$ & $795 b \pm 123$ & $12727 \mathrm{a} \pm 552$ & $10309 a \pm 336$ \\
\hline 2 & $28.1 \mathrm{~b} \pm 1.88$ & $936 \mathrm{a} \pm 138$ & $11281 b \pm 484$ & $8632 b \pm 433$ \\
\hline
\end{tabular}

Different letters indicate significant differences between treatments according to Tukey test $(p \leq 0.05)$. \pm indicate standard deviations $(n=4) .1$ and 2 refer to the first and second cropping season $(2015 / 16$ and 2016/17).

The interaction between silicon application and $\mathrm{N}$ levels affected $\operatorname{root} \mathrm{N}_{-} \mathrm{NO}_{3}{ }^{-}$, $\operatorname{root} \mathrm{N}$ $\mathrm{NH}_{4}{ }^{+}$, shoot $\mathrm{N}$, grain $\mathrm{N}$ and grain $\mathrm{Si}$ accumulation, root biomass and agronomic efficiency (Appendix A, Figure 1). The interaction between silicon application and years of study significantly affected root $\mathrm{N}^{-\mathrm{NH}_{4}}{ }^{+}$, grain $\mathrm{N}$ and grain $\mathrm{Si}$ accumulation (Appendix A, Figure 1).

\subsection{Leaf Chlorophyll Index, Inorganic $\left(\mathrm{N}-\mathrm{NH}_{4}{ }^{+}\right.$and $\left.\mathrm{N}-\mathrm{NO}_{3}{ }^{-}\right)$, Total $\mathrm{N}$ and Si Accumulation in Maize Plants}

Silicon application provided $4.6 \%$ greater LCI compared to the absence of $\mathrm{Si}$ application (Appendix A, Table 1). In addition, $\mathrm{N}$ application (low, medium and high $\mathrm{N}$ rates) provided greater $\mathrm{LCI}$ relative to control treatments (absence of side-dressing $\mathrm{N}$ fertilization) (Appendix A, Table 2).

Interaction between $\mathrm{Si}$ application and $\mathrm{N}$ levels significantly affected $\mathrm{N}-\mathrm{NO}_{3}{ }^{-}$and $\mathrm{N}-\mathrm{NH}_{4}{ }^{+}$accumulation in the root tissue (Appendix A, Figure 1a,b). The low $\left(50 \mathrm{~kg} \mathrm{~N} \mathrm{ha}^{-1}\right.$ ) and medium $\left(100 \mathrm{~kg} \mathrm{~N} \mathrm{ha}^{-1}\right) \mathrm{N}$ application levels together with Si application provided greater root $\mathrm{N}_{-} \mathrm{NO}_{3}{ }^{-}$and $\mathrm{N}-\mathrm{NH}_{4}{ }^{+}$accumulation (Appendix A, Figure 1a,b). Additionally, in the absence of $\mathrm{N}$ fertilization, $\mathrm{Si}$ application increased root $\mathrm{N}-\mathrm{NH}_{4}{ }^{+}$accumulation compared to plants from the treatments that did not receive Si (Appendix A, Figure 1b). Similarly, as verified for $\mathrm{LCI}$, increasing $\mathrm{N}$ levels provided greater ${\mathrm{N}-\mathrm{NO}_{3}}^{-}, \mathrm{N}^{-} \mathrm{NH}_{4}{ }^{+}$, total $\mathrm{N}$ and $\mathrm{Si}$ accumulation (Table 2, Figure 1). In addition, $\operatorname{root} \mathrm{N}^{-\mathrm{NH}_{4}}{ }^{+}$and $\mathrm{Si}$ accumulation were greater with $\mathrm{Si}$ application relative to the absence of $\mathrm{Si}$ application, regardless of the year of cultivation (Appendix A, Table 1, Figure 1c). Root Si accumulation showed an increase of 33\% in Si-applied plots compared to the plots without Si application (Table 1). Nitrate, $\mathrm{N}-\mathrm{NH}_{4}{ }^{+}$and total $\mathrm{N}$ accumulation in roots were greater in the first year than the second (Appendix A, Table 3, Figure 1c). 

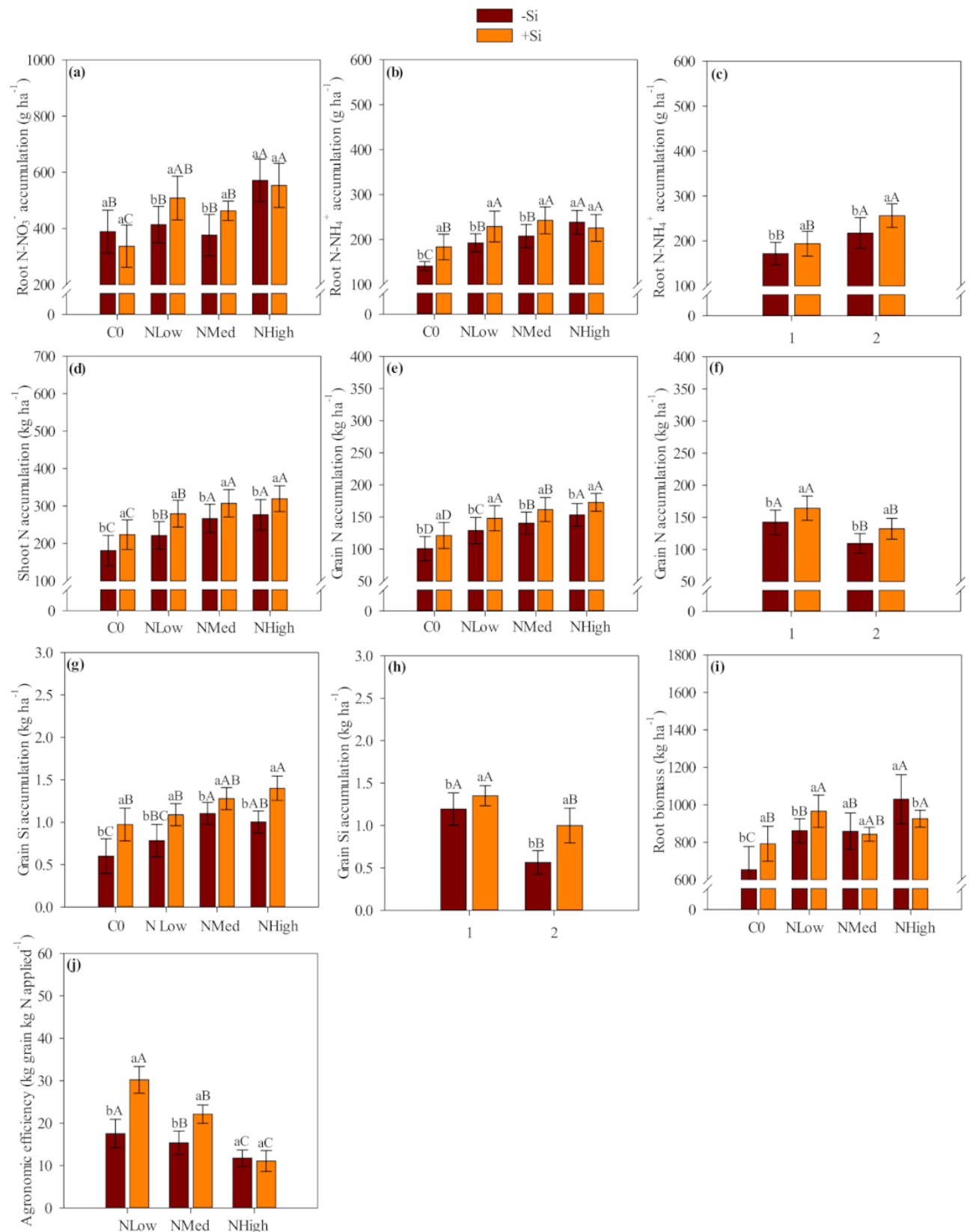

Figure 1. Maize root nitrate $\left(\mathrm{N}_{-} \mathrm{NO}_{3}{ }^{-}\right)$accumulation (a), root ammonium $\left(\mathrm{N}_{-} \mathrm{NH}_{4}{ }^{+}\right)$accumulation $(\mathbf{b}, \mathbf{c})$, shoot $\mathrm{N}$ accumulation $(\mathbf{d})$, grain $\mathrm{N}$ accumulation $(\mathbf{e}, \mathbf{f})$, grain $\mathrm{Si}$ accumulation $(\mathbf{g}, \mathbf{h})$, root biomass (i) and agronomic efficiency ( $\mathbf{j}$ ) affected by the interaction between $\mathrm{Si}$ amendment application and $\mathrm{N}$ levels or by the interaction between Si amendment application and years of study.

Interaction between $\mathrm{Si}$ amendment application and $\mathrm{N}$ levels: Lowercase letters indicate significant differences between $\mathrm{Si}$ application, and uppercase letters indicate significant differences between $\mathrm{N}$ levels according Tukey test $(p \leq 0.05)$. Interaction between Si application and years: Lowercase letters indicate significant differences between $\mathrm{Si}$ application, and uppercase letters indicate significant differences between years according to the Tukey test $(p \leq 0.05)$. Error bars indicate standard deviations $(n=4)$. $-\mathrm{Si}$ and $+\mathrm{Si}$ refer to the absence and presence of Si amendment application, respectively; C0, NLow, NMed and NHigh refer to absence, 50, 100 and $200 \mathrm{~kg} \mathrm{~N} \mathrm{ha}^{-1}$ applied in side-dressing respectively; 1 and 2 refer to the first and second cropping season (2015/16 and 2016/17).

The application of Si positively influenced $\mathrm{N}^{-\mathrm{NO}_{3}}{ }^{-}, \mathrm{N}_{-} \mathrm{NH}_{4}{ }^{+}$and $\mathrm{Si}$ accumulation in shoot compared to plots where no Si was applied (Appendix A, Table 1). Shoot Si 
accumulation increased by $19 \%$ in Si-applied plots compared to the plots that did not receive $\mathrm{Si}$ application (Table 1). The interaction between $\mathrm{Si}$ application and $\mathrm{N}$ levels significantly affected shoot total $\mathrm{N}$ accumulation (Appendix A, Figure 1d). Shoot total $\mathrm{N}$ accumulation was greater with $\mathrm{Si}$ application in both the presence and absence of $\mathrm{N}$ application. For example, shoot total $\mathrm{N}$ was $24 \%$ greater with Si application in the absence of $\mathrm{N}$ fertilization $\left(+\mathrm{Si}=224 \mathrm{vs} .-\mathrm{Si}=181 \mathrm{~kg} \mathrm{ha}^{-1}\right.$ ) (Figure 1d). Meanwhile, shoot total $\mathrm{N}$ was 26,15 and $16 \%$ greater with Si application combined with 50,100 and $200 \mathrm{~kg} \mathrm{~N} \mathrm{ha}^{-1}$, respectively $\left(50 \mathrm{~N}:+\mathrm{Si}=280\right.$ vs. $-\mathrm{Si}=222 \mathrm{~kg} \mathrm{ha}^{-1} ; 100 \mathrm{~N}:+\mathrm{Si}=308$ vs. $-\mathrm{Si}=267 \mathrm{~kg} \mathrm{ha}^{-1}$; $200 \mathrm{~N}:+\mathrm{Si}=320$ vs. $-\mathrm{Si}=277 \mathrm{~kg} \mathrm{ha}^{-1}$ ) (Figure 1d). Shoot ${\mathrm{N}-\mathrm{NO}_{3}}^{-}, \mathrm{N}^{-\mathrm{NH}_{4}}{ }^{+}$and total $\mathrm{N}$ accumulation tended to be greater with medium and high $\mathrm{N}$ application levels relative to the control and low N levels (Table 2, Figure 1). Meanwhile, shoot Si accumulation was greater with $\mathrm{N}$ application (regardless of $\mathrm{N}$ level-low, medium or high) when compared to the control (Table 2). Shoot $\mathrm{N}-\mathrm{NH}_{4}{ }^{+}$, total $\mathrm{N}$ and $\mathrm{Si}$ accumulation were greater in first than second year (Table 3).

Regarding total $\mathrm{N}$ and $\mathrm{Si}$ accumulation in the grain, $\mathrm{Si}$ application increased grain $\mathrm{N}$ and $\mathrm{Si}$ accumulation in both the presence and absence of $\mathrm{N}$ application (Figure 1e,g). Grain $\mathrm{N}$ was $21 \%$ greater with $\mathrm{Si}$ application in the absence of $\mathrm{N}$ fertilization $(+\mathrm{Si}=121$ vs. $-\mathrm{Si}=100 \mathrm{~kg} \mathrm{ha}^{-1}$ ) (Figure 1e). However, grain $\mathrm{N}$ was 15,16 and $13 \%$ greater with Si application combined with 50, 100 and $200 \mathrm{~kg} \mathrm{~N} \mathrm{ha}^{-1}$ compared with plots that did not receive $\mathrm{Si}$, respectively $\left(50 \mathrm{~N}:+\mathrm{Si}=148 \mathrm{vs} .-\mathrm{Si}=129 \mathrm{~kg} \mathrm{ha}^{-1} ; 100 \mathrm{~N}:+\mathrm{Si}=162 \mathrm{vs}\right.$. $-\mathrm{Si}=140 \mathrm{~kg} \mathrm{ha}^{-1} ; 200 \mathrm{~N}$ : $+\mathrm{Si}=173 \mathrm{vs} .-\mathrm{Si}=153 \mathrm{~kg} \mathrm{ha}^{-1}$ ) (Figure 1e). The accumulation of $\mathrm{Si}$ in grain was $62 \%$ greater with $\mathrm{Si}$ application in the absence of $\mathrm{N}$ fertilization $(+\mathrm{Si}=0.97$ vs. $-\mathrm{Si}=0.60 \mathrm{~kg} \mathrm{ha}^{-1}$ ) (Figure $1 \mathrm{~g}$ ). Similarly, grain $\mathrm{Si}$ was 41,18 and $40 \%$ greater with the application of Si combined with 50,100 and $200 \mathrm{~kg} \mathrm{~N}^{-1}$, respectively (50N: $+\mathrm{Si}=1.1$ vs. $-\mathrm{Si}=0.78 \mathrm{~kg} \mathrm{ha}^{-1} ; 100 \mathrm{~N}:+\mathrm{Si}=1.3$ vs. $-\mathrm{Si}=1.1 \mathrm{~kg} \mathrm{ha}^{-1} ; 200 \mathrm{~N}:+\mathrm{Si}=1.4$ vs. $-\mathrm{Si}=1.0 \mathrm{~kg} \mathrm{ha}^{-1}$ ) (Figure $1 \mathrm{~g}$ ). In general, grain $\mathrm{N}$ and $\mathrm{Si}$ accumulation tended to be greater with medium and high $\mathrm{N}$ levels and in the first year compared with the second year regardless of Si application (Figure 1f,h).

\subsection{Maize Biomass, Grain Yield and Agronomic Efficiency}

Root biomass increased with $\mathrm{Si}$ application in the absence of $\mathrm{N}$ fertilization and with a low $\mathrm{N}$ level relative to those plants from treatments that did not receive $\mathrm{Si}$ (Appendix A, Figure 1i). In contrast, high $\mathrm{N}$ application in plots that did not receive $\mathrm{Si}$ showed increased root biomass compared with plots that received Si (Appendix A, Figure 1i). In addition, root biomass was greater in the second year than in the first year (Appendix A, Table 3).

The application of $\mathrm{Si}$ resulted in $5.1 \%$ greater shoot biomass along with $5.2 \%$ greater grain yield compared to the absence of Si application (Table 1). Both shoot biomass and grain yield tended to be greater with the application of medium and high $\mathrm{N}$ levels compared to the control and low N levels (Table 2). Additionally, shoot biomass and grain yield were greater in first year than in the second year (Table 3).

Agronomic efficiency was increased by 73 and $44 \%$ with Si application under low and medium $\mathrm{N}$ levels compared to plots that did not receive $\mathrm{Si}$ application $(50 \mathrm{~N}:+\mathrm{Si}=30.2$ vs. $-\mathrm{Si}=17.5 \mathrm{~kg}$ grains $\mathrm{kg} \mathrm{N}$ applied ${ }^{-1} ; 100 \mathrm{~N}:+\mathrm{Si}=22.1$ vs. $-\mathrm{Si}=15.4 \mathrm{~kg}$ grains $\mathrm{kg} \mathrm{N}$ applied $^{-1}$ ) (Figure 1j). Agronomic efficiency tended to decrease with increasing $\mathrm{N}$ levels, regardless of Si application (Figure 1j).

\subsection{Pearson's Correlation among Si Accumulation in Maize Plant and the Other Evaluated Parameters}

Overall, Pearson's correlation was positive among Si accumulation in maize plant (root, shoot and grain) and biomass components (root, shoot biomass and grain yield), agronomic efficiency, LCI, $\mathrm{N}$ accumulation in plant ( $\mathrm{N}$ accumulation in shoot, root and grain) and inorganic $\mathrm{N}$ accumulation in plant $\left(\mathrm{N}^{-\mathrm{NO}_{3}}{ }^{-}\right.$and $\mathrm{N}^{-\mathrm{NH}_{4}}{ }^{+}$accumulation in shoot and root) (Figure 2). In contrast, $\mathrm{Si}$ grain accumulation was negatively correlated with total $\mathrm{N}$ and $\mathrm{N}^{-\mathrm{NO}_{3}}{ }^{-}$accumulation in the root tissue (Figure 2). 


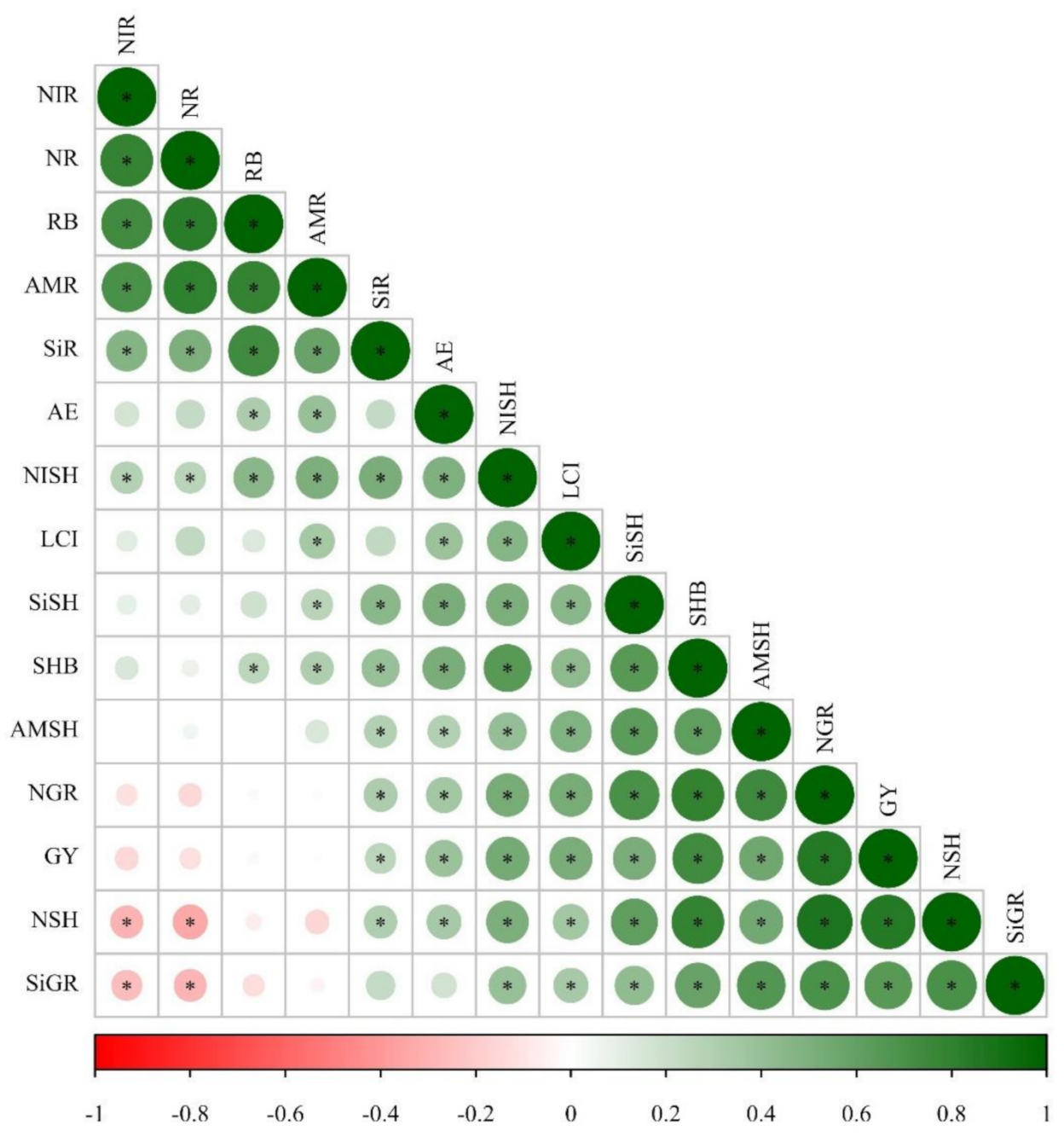

Correlation coefficient

Figure 2. Heatmap showing the Pearson's correlation among the analyzed parameters in maize plants in response to $\mathrm{Si}$ application and $\mathrm{N}$ levels. * indicates significant relationship $(p \leq 0.05)$. Abbreviation:

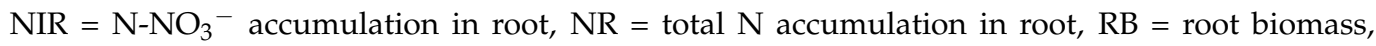
$\mathrm{AMR}=\mathrm{N}_{-} \mathrm{NH}_{4}{ }^{+}$accumulation in root, $\mathrm{SiR}=\mathrm{Si}$ accumulation in root, $\mathrm{AE}=$ agronomic efficiency, $\mathrm{NISH}=\mathrm{N}_{-} \mathrm{NO}_{3}{ }^{-}$accumulation in shoot, $\mathrm{LCI}=$ leaf chlorophyll index, $\mathrm{SiSH}=\mathrm{Si}$ accumulation in shoot, $\mathrm{SHB}=$ shoot biomass, $\mathrm{AMSH}=\mathrm{N}-\mathrm{NH}_{4}{ }^{+}$accumulation in shoot, $\mathrm{NGR}=$ total $\mathrm{N}$ accumulation in grain, $\mathrm{GY}=$ grain yield, $\mathrm{NSH}=$ total $\mathrm{N}$ accumulation in shoot, $\mathrm{SiGR}=\mathrm{Si}$ accumulation in grain .

\subsection{Summary of Statistical Analysis: Wheat}

Silicon application significantly affected $\operatorname{root} \mathrm{N}^{-\mathrm{NO}_{3}}{ }^{-}$, $\operatorname{root} \mathrm{N}-\mathrm{NH}_{4}{ }^{+}$, shoot $\mathrm{N}^{-\mathrm{NO}_{3}}{ }^{-}$, shoot $\mathrm{N}-\mathrm{NH}_{4}{ }^{+}$, shoot $\mathrm{N}$, shoot $\mathrm{Si}$, grain $\mathrm{N}$ and grain $\mathrm{Si}$ accumulation, shoot biomass and

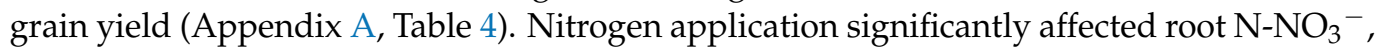
root $\mathrm{N}-\mathrm{NH}_{4}{ }^{+}$, shoot $\mathrm{N}-\mathrm{NO}_{3}{ }^{-}$, shoot $\mathrm{N}-\mathrm{NH}_{4}{ }^{+}$, shoot $\mathrm{N}$, shoot $\mathrm{Si}$ accumulation and grain $\mathrm{N}$ accumulation, shoot biomass and grain yield (Appendix A, Table 5). Years of study significantly affected root $\mathrm{N}^{-\mathrm{NO}_{3}}{ }^{-}, \operatorname{root} \mathrm{N}-\mathrm{NH}_{4}{ }^{+}, \operatorname{root} \mathrm{N}$, shoot $\mathrm{N}-\mathrm{NO}_{3}{ }^{-}$, shoot $\mathrm{N}^{-} \mathrm{NH}_{4}{ }^{+}$, shoot $\mathrm{Si}$, grain $\mathrm{N}$ and grain $\mathrm{Si}$ accumulation; shoot biomass and grain yield (Appendix $\mathrm{A}$, Table 6). 
Table 4. Wheat root nitrate $\left(\mathrm{N}_{-} \mathrm{NO}_{3}{ }^{-}\right)$; root ammonium $\left(\mathrm{N}-\mathrm{NH}_{4}{ }^{+}\right)$accumulation; shoot $\mathrm{N}^{-\mathrm{NO}_{3}}{ }^{-}$; shoot $\mathrm{N}-\mathrm{NH}_{4}{ }^{+}$; shoot $\mathrm{N}$; shoot $\mathrm{Si}$ accumulation; grain $\mathrm{N}$; grain $\mathrm{Si}$ accumulation; shoot biomass and grain yield as a function of $\mathrm{Si}$ amendment application.

\begin{tabular}{|c|c|c|c|c|c|}
\hline Sources & $\begin{array}{c}\text { Root } \\
\mathrm{N}^{-\mathrm{NO}_{3}}{ }^{-}\end{array}$ & $\underset{\mathrm{N}^{-\mathrm{NH}_{4}}}{{ }^{+}}$ & $\begin{array}{c}\text { Shoot } \\
\mathrm{N}^{-\mathrm{NO}_{3}}{ }^{-}\end{array}$ & $\begin{array}{c}\text { Shoot } \\
\mathrm{N}^{-\mathrm{NH}_{4}}{ }^{+}\end{array}$ & Shoot N \\
\hline & \multicolumn{4}{|c|}{$\left(\mathrm{g} \mathrm{ha}^{-1}\right)$} & $\left(\mathrm{kg} \mathrm{ha}^{-1}\right)$ \\
\hline$-\mathrm{Si}$ & $121 b \pm 7.93$ & $83.7 b \pm 4.59$ & $1336 b \pm 143$ & $1116 \mathrm{~b} \pm 130$ & $127 \mathrm{~b} \pm 11.1$ \\
\hline$+\mathrm{Si}$ & $143 \mathrm{a} \pm 8.85$ & $99.2 \mathrm{a} \pm 5.52$ & $1629 a \pm 146$ & $1319 a \pm 116$ & $141 \mathrm{a} \pm 10.5$ \\
\hline \multirow[t]{2}{*}{ Sources } & Shoot Si & Grain N & Grain Si & $\begin{array}{c}\text { Shoot } \\
\text { Biomass }\end{array}$ & Grain Yield \\
\hline & \multicolumn{5}{|c|}{$\left(\mathrm{kg} \mathrm{ha}^{-1}\right)$} \\
\hline$-\mathrm{Si}$ & $20.44 b \pm 2.49$ & $102 b \pm 7.52$ & $3.01 \mathrm{~b} \pm 0.32$ & $4841 b \pm 218$ & $3925 b \pm 154$ \\
\hline$+\mathrm{Si}$ & $29.00 \mathrm{a} \pm 3.72$ & $118 \mathrm{a} \pm 7.22$ & $4.07 \mathrm{a} \pm 0.55$ & $5491 \mathrm{a} \pm 238$ & $4223 \mathrm{a} \pm 130$ \\
\hline
\end{tabular}

Different letters indicate significant differences between treatments according to Tukey test $(p \leq 0.05)$. \pm indicate standard deviations $(n=4)$. $-\mathrm{Si}$ and $+\mathrm{Si}$ refers to absence and presence of $\mathrm{Si}$ amendment application.

Table 5. Wheat root nitrate $\left(\mathrm{N}_{-} \mathrm{NO}_{3}{ }^{-}\right)$; root ammonium $\left(\mathrm{N}-\mathrm{NH}_{4}{ }^{+}\right)$accumulation; shoot $\mathrm{N}^{-\mathrm{NO}_{3}}{ }^{-}$; shoot $\mathrm{N}-\mathrm{NH}_{4}{ }^{+}$; shoot $\mathrm{N}$; shoot $\mathrm{Si}$ accumulation; grain $\mathrm{N}$ accumulation; shoot biomass and grain yield as a function of $\mathrm{N}$ levels.

\begin{tabular}{|c|c|c|c|c|c|}
\hline N Rates & Root N-NO ${ }_{3}^{-}$ & $\operatorname{Root} \mathrm{N}-\mathrm{NH}_{4}{ }^{+}$ & $\begin{array}{c}\text { Shoot } \\
\mathrm{N}^{-\mathrm{NO}_{3}}{ }^{-}\end{array}$ & Shoot N-NH${ }_{4}^{+}$ & Shoot N \\
\hline & \multicolumn{4}{|c|}{$\left(\mathrm{g} \mathrm{ha}^{-1}\right)$} & $\left(\mathrm{kg} \mathrm{ha}^{-1}\right)$ \\
\hline Control $(\mathrm{C} \mathrm{ON})$ & $104 c \pm 7.85$ & $84.2 b \pm 5.12$ & $1218 c \pm 119$ & $1002 c \pm 119$ & $109 c \pm 11.4$ \\
\hline N Low & $122 b c \pm 8.27$ & $87.5 \mathrm{ab} \pm 5.32$ & $1475 b \pm 142$ & $1109 b c \pm 106$ & $122 \mathrm{~b} \pm 12.9$ \\
\hline N Medium & $145 \mathrm{ab} \pm 8.32$ & $92.3 \mathrm{ab} \pm 5.28$ & $1649 a b \pm 119$ & $1353 b \pm 104$ & $143 b \pm 10.1$ \\
\hline N High & $156 \mathrm{a} \pm 8.67$ & $101 \mathrm{a} \pm 4.99$ & $1789 a \pm 124$ & $1426 \mathrm{a} \pm 102$ & $148 \mathrm{a} \pm 11.1$ \\
\hline \multirow[t]{2}{*}{ N Rates } & Shoot Si & Grain N & $\begin{array}{c}\text { Shoot } \\
\text { Biomass }\end{array}$ & \multicolumn{2}{|c|}{ Grain Yield } \\
\hline & \multicolumn{5}{|c|}{$\left(\mathrm{kg} \mathrm{ha}^{-1}\right)$} \\
\hline Control $(\mathrm{C} 0 \mathrm{~N})$ & $19.4 b \pm 1.81$ & $97.9 b \pm 7.78$ & $4617 b \pm 243$ & \multicolumn{2}{|c|}{$3540 b \pm 242$} \\
\hline N Low & $24.2 \mathrm{a} \pm 2.03$ & $106 a b \pm 7.62$ & $5198 a b \pm 241$ & \multicolumn{2}{|c|}{$4174 \mathrm{a} \pm 190$} \\
\hline $\mathrm{N}$ Medium & $26.5 \mathrm{a} \pm 1.69$ & $119 a \pm 8.56$ & $5367 a b \pm 248$ & \multicolumn{2}{|c|}{$4427 \mathrm{a} \pm 205$} \\
\hline N High & $28.6 \mathrm{a} \pm 1.96$ & $115 \mathrm{a} \pm 7.35$ & $5581 \mathrm{a} \pm 254$ & \multicolumn{2}{|c|}{$4154 \mathrm{a} \pm 189$} \\
\hline
\end{tabular}

Different letters indicate significant differences between treatments according to Tukey test $(p \leq 0.05) . \pm$ indicate standard deviations $(n=4)$. Ctl, Low, Med and High refers to absence, 50, 100 and $200 \mathrm{~kg} \mathrm{~N} \mathrm{ha}^{-1}$ applied in side-dressing respectively.

Table 6. Wheat root nitrate $\left({\mathrm{N}-\mathrm{NO}_{3}}^{-}\right)$; root ammonium $\left(\mathrm{N}-\mathrm{NH}_{4}{ }^{+}\right)$; root $\mathrm{N}$ accumulation; shoot $\mathrm{N}-\mathrm{NO}_{3}{ }^{-}$; shoot $\mathrm{N}-\mathrm{NH}_{4}{ }^{+}$; shoot $\mathrm{Si}$ accumulation; grain $\mathrm{N}$; grain $\mathrm{Si}$ accumulation; shoot biomass and grain yield as a function of years of study.

\begin{tabular}{|c|c|c|c|c|c|}
\hline Year & $\begin{array}{c}\text { Root } \\
\mathrm{N}-\mathrm{NO}_{3}-\end{array}$ & $\underset{\mathrm{N}_{-} \mathrm{NH}_{4}}{\text { Root }}$ & $\operatorname{Root} \mathbf{N}$ & $\begin{array}{c}\text { Shoot } \\
\mathrm{N}^{-\mathrm{NO}_{3}}-\end{array}$ & $\begin{array}{c}\text { Shoot } \\
\mathrm{N}^{-\mathrm{NH}_{4}}{ }^{+}\end{array}$ \\
\hline & \multicolumn{2}{|c|}{$\left(\mathrm{g} \mathrm{ha}^{-1}\right)$} & $\left(\mathrm{kg} \mathrm{ha}^{-1}\right)$ & \multicolumn{2}{|c|}{$\left(\mathrm{g} \mathrm{ha}^{-1}\right)$} \\
\hline 1 & $146 \mathrm{a} \pm 7.14$ & $97.8 \mathrm{a} \pm 5.81$ & $5.86 \mathrm{a} \pm 0.59$ & $1580 \mathrm{a} \pm 111$ & $1275 \mathrm{a} \pm 107$ \\
\hline 2 & $117 \mathrm{~b} \pm 8.24$ & $85.1 b \pm 5.23$ & $4.45 \mathrm{~b} \pm 0.54$ & $1385 \mathrm{~b} \pm 154$ & $1160 \mathrm{~b} \pm 108$ \\
\hline \multirow[t]{2}{*}{ Year } & Shoot Si & Grain N & Grain Si & $\begin{array}{c}\text { Shoot } \\
\text { Biomass }\end{array}$ & Grain Yield \\
\hline & & & $\left(\mathrm{kg} \mathrm{ha}^{-1}\right)$ & & \\
\hline 1 & $37.4 \mathrm{a} \pm 2.41$ & $116 \mathrm{a} \pm 8.27$ & $4.83 \mathrm{a} \pm 0.50$ & $5512 \mathrm{a} \pm 244$ & $4273 a \pm 243$ \\
\hline 2 & $11.9 \mathrm{~b} \pm 2.1$ & $103 b \pm 7.53$ & $2.25 b \pm 0.65$ & $4820 \mathrm{~b} \pm 274$ & $3875 b \pm 201$ \\
\hline
\end{tabular}

Different letters indicate significant differences between treatments according to Tukey test $(p \leq 0.05)$. \pm indicate standard deviations $(n=4) .1$ and 2 refers to the first and second cropping season (2016 and 2017). 
The interaction between silicon application and $\mathrm{N}$ levels affected LCI, root Si accumulation, root biomass and agronomic efficiency (Appendix A, Figure 3). The interaction between silicon application and years of study significantly affected LCI, root Si accumulation and root biomass (Appendix A, Figure 3).
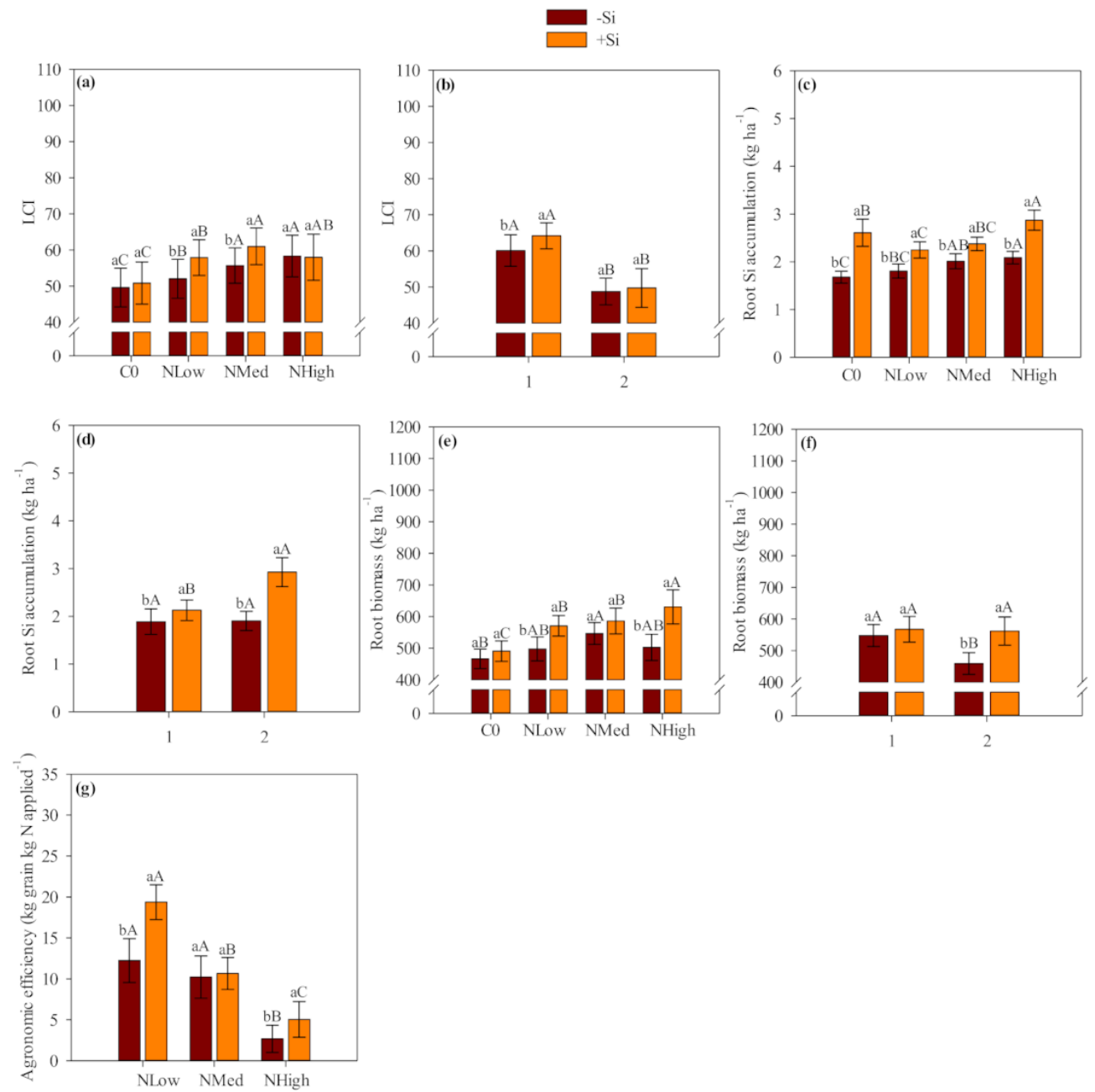

Figure 3. Wheat leaf chlorophyll index (LCI) $(\mathbf{a}, \mathbf{b})$, root $\mathrm{Si}$ accumulation $(\mathbf{c}, \mathbf{d})$, root biomass $(\mathbf{e}, \mathbf{f})$ and agronomic efficiency ( $\mathrm{g}$ ) affected by the interaction between $\mathrm{Si}$ amendment application and $\mathrm{N}$ levels or by the interaction between $\mathrm{Si}$ amendment application and years of study.

2.6. Leaf Chlorophyll Index, Inorganic $\left(\mathrm{N}-\mathrm{NH}_{4}{ }^{+}\right.$and $\left.\mathrm{N}_{-} \mathrm{NO}_{3}{ }^{-}\right)$, Total $\mathrm{N}$ and Si Accumulation in Wheat Plants

Leaf chlorophyll index was 12 and 8.9\% greater with Si application when coupled with low and medium $\mathrm{N}$ levels compared to without $\mathrm{Si}$ application $(50 \mathrm{~N}$ : +Si $=58$ vs $-\mathrm{Si}=52 ; 100 \mathrm{~N}:+\mathrm{Si}=61$ vs. $-\mathrm{Si}=56)($ Appendix B, Figure 3a). Additionally, higher LCI was observed with medium and high $\mathrm{N}$ levels compared to control and low $\mathrm{N}$ levels regardless of Si application (Appendix B, Figure 3a). In addition, LCI was greater in the first year than in the second year (Figure 3a).

Interaction between Si amendment application and $\mathrm{N}$ levels: Lowercase letters indicate significant differences between Si application, and uppercase letters indicate significant differences between $\mathrm{N}$ levels according Tukey test $(p \leq 0.05)$. Interaction between Si application and years: Lowercase letters indicate significant differences between Si application, and uppercase letters indicate significant differences between years according Tukey test $(p \leq 0.05)$. Error bars indicate standard deviations $(n=4)$. $-\mathrm{Si}$ and $+\mathrm{Si}$ refers to absence and presence of Si amendment application, respectively; C0, NLow, NMed and NHigh 
refers to absence, 50, 100 and $200 \mathrm{~kg} \mathrm{~N}$ ha $^{-1}$ applied in side-dressing respectively; 1 and 2 refers to the first and second cropping season (2015/16 and 2016/17).

Nitrate and $\mathrm{N}-\mathrm{NH}_{4}{ }^{+}$accumulation in the root were greater with $\mathrm{Si}$ application relative to the absence of $\mathrm{Si}$ and tended to increase with high $\mathrm{N}$ application compared to control, low and medium $\mathrm{N}$ levels (Appendix $\mathrm{B}$, Tables 4 and 5). Root inorganic $\left(\mathrm{N}^{-\mathrm{NO}_{3}}{ }^{-}, \mathrm{N}^{-\mathrm{NH}_{4}}{ }^{+}\right)$ and total $\mathrm{N}$ were greater in the first year than in the second year (Appendix $\mathrm{B}$, Table 6). Interaction between $\mathrm{Si}$ application and $\mathrm{N}$ levels significantly affected root $\mathrm{Si}$ accumulation (Appendix B, Figure 3c). The root Si accumulation was 53\% greater with $\mathrm{Si}$ application in the absence of $\mathrm{N}$ fertilization ( $\mathrm{Si}=2.6 \mathrm{vs} .-\mathrm{Si}=1.7 \mathrm{~kg} \mathrm{ha}^{-1}$ ) (Figure 3c). Additionally, root $\mathrm{Si}$ accumulation was 28,20 and $38 \%$ greater with Si application combined with 50, 100 and $200 \mathrm{~kg} \mathrm{Nha}^{-1}$, respectively $\left(50 \mathrm{~N}:+\mathrm{Si}=2.3 \mathrm{vs} .-\mathrm{Si}=1.8 \mathrm{~kg} \mathrm{ha}^{-1} ; 100 \mathrm{~N}:+\mathrm{Si}=2.4\right.$ vs. $-\mathrm{Si}=2.0 \mathrm{~kg} \mathrm{ha}^{-1} ; 200 \mathrm{~N}:+\mathrm{Si}=2.9$ vs. $-\mathrm{Si}=2.1 \mathrm{~kg} \mathrm{ha}^{-1}$ ) (Figure 3c).

Nitrate, ${\mathrm{N}-\mathrm{NH}_{4}}^{+}$, total $\mathrm{N}$ and $\mathrm{Si}$ accumulation were increased with $\mathrm{Si}$ application (Appendix B, Table 4). We verified an increase of 10 and $45 \%$ in total $\mathrm{N}$ and $\mathrm{Si}$ accumulation in plots that received $\mathrm{Si}$ application compared to plots that did not receive $\mathrm{Si}$ application (Table 4). Inorganic $\mathrm{N}\left(\mathrm{N}^{-N_{3}}{ }_{3}^{-}\right.$and $\left.\mathrm{N}-\mathrm{NH}_{4}{ }^{+}\right)$, total $\mathrm{N}$ and $\mathrm{Si}$ accumulation in shoot tissue tended to be greater with medium and high $\mathrm{N}$ application levels compared to the

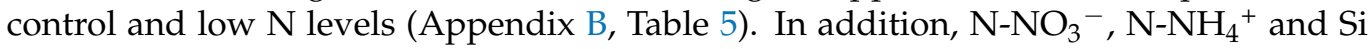
accumulation were greater in the first year than in the second year (Appendix B, Table 6).

Nitrogen and Si accumulation in the grain were 17 and $37 \%$ greater with Si application compared to the absence of $\mathrm{Si}$ (Appendix B, Table 4). Both grain N and $\mathrm{Si}$ accumulation were greater in the first year than in the second year (Appendix B, Table 6). Similarly, N accumulation in the shoot and grain increased with medium and high $\mathrm{N}$ application levels compared to the control and low N levels (Appendix B, Table 5).

\subsection{Wheat Biomass, Grain Yield and Agronomic Efficiency}

Root biomass was greater in plot receiving Si combined with low and high $\mathrm{N}$ levels application relative to plots that did not receive Si application (Appendix B, Figure 3e). Medium and high $\mathrm{N}$ levels provided greater root biomass coupled or not with $\mathrm{Si}$ application (Appendix B, Figure 3e). The positive effect of Si application was more evident in the second year due to the greater root biomass observed in plots receiving Si compared with plot that did not receive Si application (Appendix B, Figure 3f).

Shoot biomass and grain yield were increased by 13 and $7.6 \%$ with $\mathrm{Si}$ application compared to the plots that did not receive Si (Appendix B, Table 4). Shoot biomass was greater with medium and high $\mathrm{N}$ application levels compared to the control and low $\mathrm{N}$ levels (Appendix B, Table 5). However, grain yield was found to be greater with medium $\mathrm{N}$ level compared to the control, low and high $\mathrm{N}$ levels (Appendix B, Table 5).

Agronomic efficiency was 59 and $85 \%$ greater with Si application combined with low and high $\mathrm{N}$ levels compared to the absence of $\mathrm{Si}$ application $(50 \mathrm{~N}:+\mathrm{Si}=19.4 \mathrm{vs} .-\mathrm{Si}=12.2 \mathrm{~kg}$ grain $\mathrm{kg} \mathrm{N}$ applied ${ }^{-1} 100 \mathrm{~N}:+\mathrm{Si}=5.0$ vs. $-\mathrm{Si}=2.7 \mathrm{~kg}_{\text {grain }} \mathrm{kg} \mathrm{N}$ applied $\left.{ }^{-1}\right)($ Appendix $\mathrm{B}$, Figure $3 \mathrm{~g}$ ). The $\mathrm{Si}$ application along with increasing N levels (low $>$ medium $>$ high) tended to reduce agronomic efficiency (Appendix B, Figure 3g). Whereas, in the absence of Si application, the high $\mathrm{N}$ application level decreased agronomic efficiency compared to low and medium $\mathrm{N}$ levels (Figure 3g).

\subsection{Pearson's Correlation among Si Accumulation in Wheat Plants and the Other Evaluated Parameters}

Similarly as verified in maize, overall, Pearson's correlation was positive among Si accumulation in wheat plant (root, shoot and grain) and biomass components (root, shoot biomass and grain yield), LCI, $\mathrm{N}$ accumulation in plant ( $\mathrm{N}$ accumulation in shoot, root and grain) and inorganic $\mathrm{N}$ accumulation in plant $\left(\mathrm{N}^{-\mathrm{NO}_{3}}{ }^{-}\right.$and $\mathrm{N}-\mathrm{NH}_{4}{ }^{+}$accumulation in shoot and root) (Figure 4). In contrast, Si root accumulation was negatively correlated with LCI (Figure 4). Meanwhile, Si grain accumulation was negatively correlated with shoot biomass and $\mathrm{N}$ root accumulation (Figure 4). 


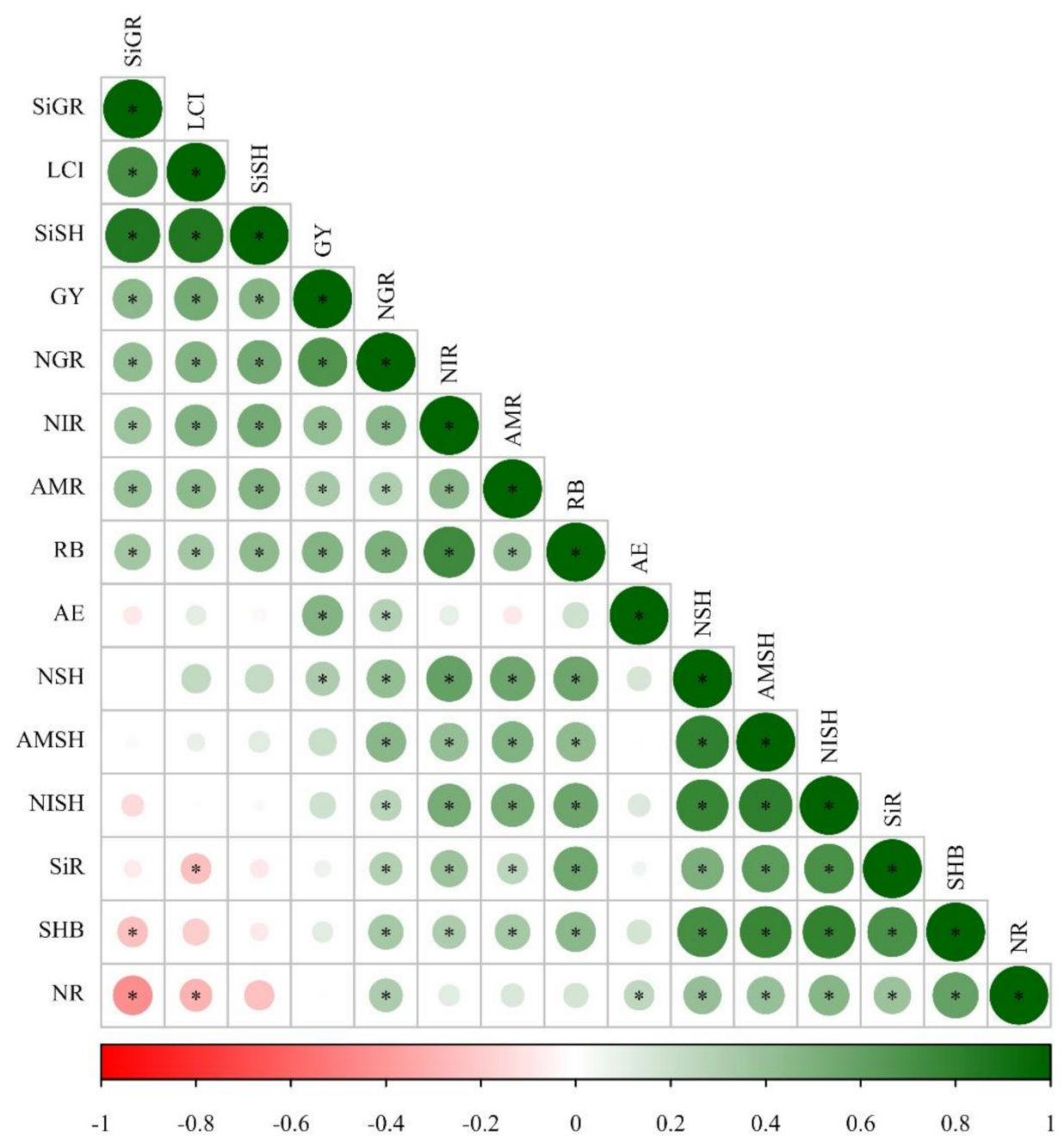

Correlation coefficient

Figure 4. Heatmap showing the Pearson's correlation among the analyzed parameters in wheat plants in response to $\mathrm{Si}$ application and $\mathrm{N}$ levels. * indicates significant relationship $(p \leq 0.05)$. Abbreviation:

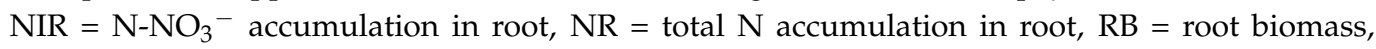
$\mathrm{AMR}=\mathrm{N}-\mathrm{NH}_{4}{ }^{+}$accumulation in root, $\mathrm{SiR}=\mathrm{Si}$ accumulation in root, $\mathrm{AE}=$ agronomic efficiency,

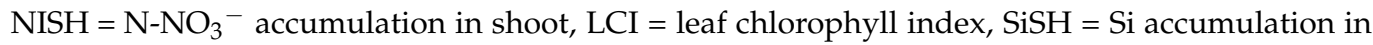
shoot, $\mathrm{SHB}=$ shoot biomass, $\mathrm{AMSH}=\mathrm{N}-\mathrm{NH}_{4}{ }^{+}$accumulation in shoot, $\mathrm{NGR}=$ total $\mathrm{N}$ accumulation in grain, $\mathrm{GY}=$ grain yield, $\mathrm{NSH}=$ total $\mathrm{N}$ accumulation in shoot, $\mathrm{SiGR}=\mathrm{Si}$ accumulation in grain .

\section{Discussion}

Our results showed that $\mathrm{Ca}$ and $\mathrm{Mg}$ silicate was an effective source of $\mathrm{Si}$ which increased Si accumulation in the shoots and roots of field-grown maize and wheat crops. Most of the absorbed Si was accumulated in the shoot tissue, where it is deposited within the leaf epidermis through plant transpiration flux. The $\mathrm{Si}$ inside plant epidermis was condensed into a polymerized silica gel $\left(\mathrm{SiO}_{2} \mathrm{nH}_{2} \mathrm{O}\right)$ known as a phytolith that is immobile and developed a protective structural layer in the plant cell walls [36-38]. Interestingly, we verified that grain $\mathrm{Si}$ accumulation in maize and wheat also increased with silicate application. Some plant species can take up and translocate large quantities of $\mathrm{Si}$ in the aboveground tissue due to specific Si transporters [39]. For example, Ma et al. [40] reported that the transport of $\mathrm{Si}$ from soil to the rice panicles is mediated by different transporters. According to these authors, Lsi1, belonging to a NIP group of the aquaporin family, is responsible for the uptake of Si from soil into the root cells in both dicots and monocots 
although its expression patterns and cellular localization differ with plant species. The subsequent transport of $\mathrm{Si}$ out of the root cells towards the stele is medicated by an active efflux transporter, Lsi2 [40]. Silicon in the xylem sap is presented in the form of monosilicic acid and is unloaded by Lsi6, a homolog of Lsi1 in rice [40]. Lsi6 is also involved in the inter-vascular transfer of $\mathrm{Si}$ at the node, which is necessary for preferential Si distribution to the panicles [40].

Silicon-applied treatments showed a total $\mathrm{Si}$ accumulation (shoot, root and grain) of $43 \mathrm{~kg} \mathrm{Si} \mathrm{ha}{ }^{-1}$ for maize and $36 \mathrm{~kg} \mathrm{Si} \mathrm{ha}{ }^{-1}$ for the wheat crop. Some previous studies reported that sugarcane (Saccharum officinarum L.) has the potential to take up the largest amount of silicon (300-700 kg of Si ha ${ }^{-1}$ ), followed by rice (150-300 $\mathrm{kg}$ of Si ha ${ }^{-1}$ ), and wheat (30-150 kg of Si ha ${ }^{-1}$ ) [41]. On an average, plants can absorb anywhere from 30 to $300 \mathrm{~kg} \mathrm{Si} \mathrm{ha}^{-1}$ [38,42]. Such values of absorbed silicon cannot be fully explained by passive absorption because the upper $0.20 \mathrm{~m}$ soil layer contains only an average of $0.1-1.6 \mathrm{~kg} \mathrm{Si} \mathrm{ha}^{-1}$ as monosilicic acid [41]. The above high Si accumulation observed in maize plants indicated that this crop could be considered one of the most efficient $\mathrm{Si}$ accumulators in Poaceae, after sugarcane and rice.

Leaf chlorophyll index (LCI) was benefited by Si application in maize. The Si application also benefited LCI in wheat, however the positive response was more evident in the first year than in the second wheat crop season when coupled with low and medium $\mathrm{N}$ levels. Silicon fertilization can benefit the foliar architecture of plants by improving erectness of leaves which leads to greater light interception, reducing self-shading and lodging, postponing senescence and improving photosynthesis [39,43]. Additionally, $\mathrm{Si}$ application had greater influence on the agronomic efficiency of the $\mathrm{N}$ fertilizer applied to the maize and wheat crops. Specifically, under low and medium $\mathrm{N}$ levels, agronomic efficiency was increased by 73 and $44 \%$ with Si application in maize, respectively. Similarly, under low and high $\mathrm{N}$ levels, agronomic efficiency was increased by 58 and $85 \%$ with $\mathrm{Si}$ application in wheat. Silicon application can enhance primary metabolism by decreasing the transpiration rate [44] and improving photosynthesis [45,46] and nutrient uptake [47]. Thereby, the greater Si uptake and LCI verified in our study together with enhanced agronomic efficiency of $\mathrm{N}$-applied levels due to silicate application positively influenced the inorganic $\mathrm{N}$ accumulation in maize and wheat root and shoot, and grain $\mathrm{N}$ accumulation, leading to a greater shoot biomass and grain yield. The positive Pearson's correlation along with Si accumulation in maize and wheat plants, LCI, and $\mathrm{N}$ accumulation in plant and biomass components support this hypothesis (Figures 2 and 4).

The results suggested that $\mathrm{Si}$ application increases $\mathrm{N}$ agronomic efficiency and grain yield, so presumably less $\mathrm{N}$ would need to be applied when used in combination with $\mathrm{Si}$. Based on the verified maize and wheat grain yield, linear interpolation was accessed (the equations were presented as Appendix $\mathrm{C}$ ). It would be possible to reduce $\mathrm{N}$ application from $180-185$ to $100 \mathrm{~kg} \mathrm{~N} \mathrm{ha}^{-1}$ (for maize) and from 195-200 to $100 \mathrm{~kg} \mathrm{~N} \mathrm{ha}^{-1}$ (for wheat) when silicate was applied, with similar grain yield (maize: $-\mathrm{Si} 180-185 \mathrm{~N}=10223-10264 \mathrm{~kg} \mathrm{ha}^{-1}$ vs. + Si $100 \mathrm{~N}=10252 \mathrm{~kg} \mathrm{ha}^{-1}$; wheat: $-\mathrm{Si} 195-200 \mathrm{~N}=4385-4405 \mathrm{~kg} \mathrm{ha}^{-1}$ vs. $+\mathrm{Si}$ $100 \mathrm{~N}=4392 \mathrm{~kg} \mathrm{ha}^{-1}$ ) (Appendix C). Positive responses to Si application, mainly under abiotic and biotic environments, were reported elsewhere for different plant species [48-52]. Here, we have focused on the positive effects of $\mathrm{Si}$ application on $\mathrm{N}$ agronomic efficiency under harsh field growing conditions, such as drought and high temperatures which are common under tropical agriculture conditions. In our study, although total rainfall was relatively well distributed during maize growing seasons, high temperatures were observed during the field trial (maximum and minimum temperature above $35^{\circ} \mathrm{C}$ and $20^{\circ} \mathrm{C}$ in most of the cases, respectively) (Figure 5). Regarding wheat crop, supplementary irrigation was performed, although total rainfall was poor and not well distributed during the wheat growing seasons (Figure 5). In addition, high temperatures were observed during the field trial (maximum and minimum temperature above $30{ }^{\circ} \mathrm{C}$ and $15^{\circ} \mathrm{C}$ in most of the cases, respectively). Thus, plant growth response to $\mathrm{Si}$ application under tropical 
conditions would be more noticeable, as verified in our study, especially for Si accumulator crops such as maize and wheat, as we discussed above.

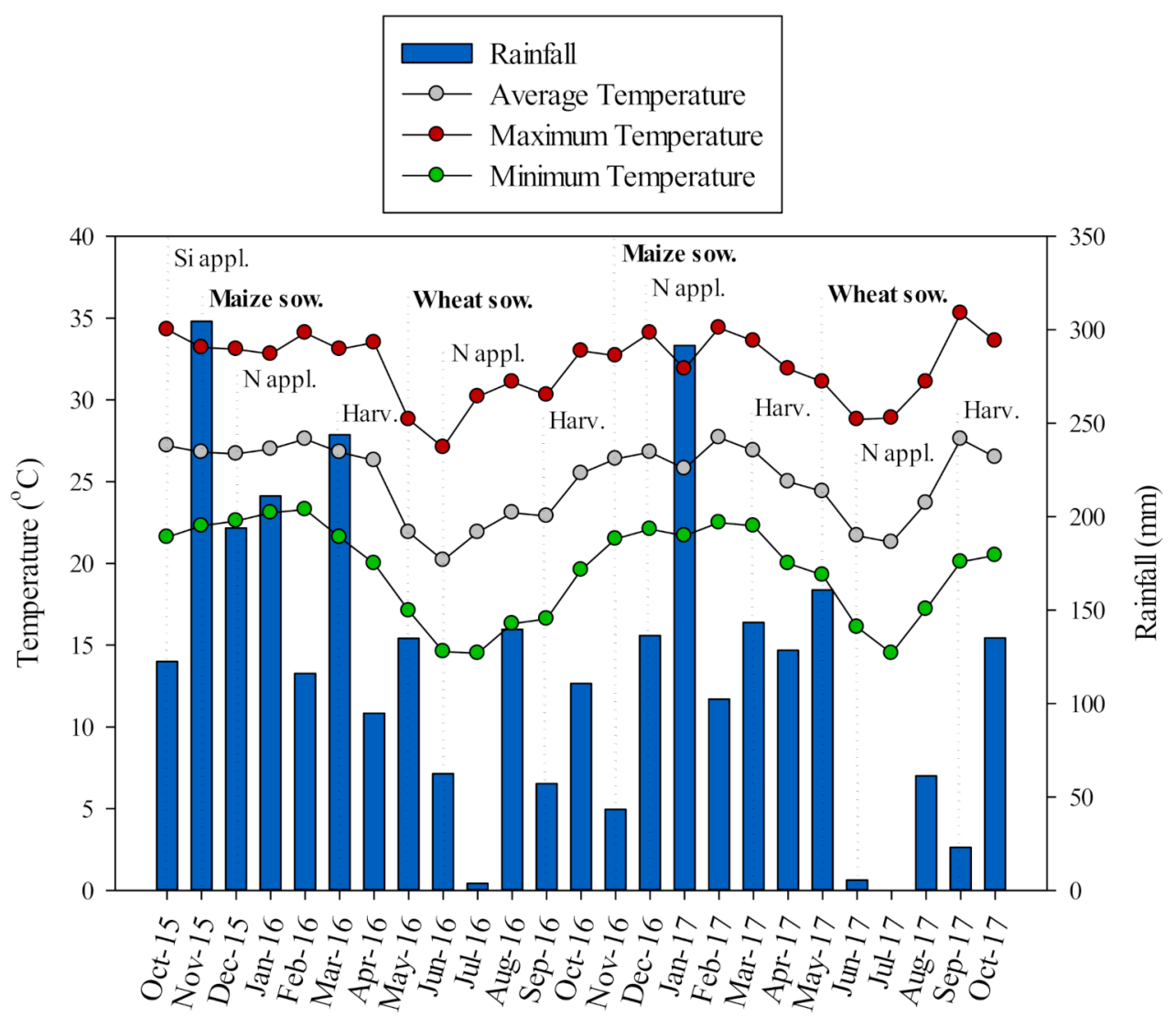

Figure 5. Rainfall, and temperatures (minimum, average and maximum) obtained from the weather station located in the Education and Research Farm of College of Engineering of Ilha Solteira/São Paulo State University (FEIS/UNESP) during the period of October 2015 to October 2017. Vertical dotted lines represent the Si-amendment source application, maize and wheat sowing, $\mathrm{N}$ application in side-dressing and harvest dates, respectively.

Although verifying a positive residual effect of $\mathrm{Si}$ application, our study indicated that the influence of residual Si-amendment source was less evident in each successive crop season. For example, shoot and grain Si accumulation was greater in the first than second maize cropping season. In addition, the shoot and grain $\mathrm{N}$ accumulation, and the shoot biomass and grain yield followed the same trend as observed for the shoot and grain $\mathrm{Si}$ accumulation. Our study observed the same behavior in wheat crop, with a reduced shoot and grain $\mathrm{Si}$ accumulation followed by reduced LCI, grain N accumulation, shoot biomass and grain yield. We could expect this behavior once Si uptakes by maize-wheat crops are higher and coupled with no other nutrient application would reduce $\mathrm{Si}$ availability along successive crop seasons. Thus, adequate $\mathrm{Si}$ replenishment along continuous successive cropping seasons are required to avoid this element depletion and impaired cereal growth and yield.

\section{Materials and Methods}

\subsection{Site Description}

The study was carried out under field conditions in Selvíria (Savannah regionBrazilian Cerrado), state of Mato Grosso do Sul, Brazil $\left(20^{\circ} 22^{\prime} \mathrm{S}\right.$ and $51^{\circ} 22^{\prime} \mathrm{W}, 335 \mathrm{~m}$ above sea level (a.s.l.), during the 2015 to 2017 growing seasons. The soil was classified as Rhodic Haplustox (Clayey Oxisol) according to the Soil Survey Staff [53]. Twenty random 
soil samples were collected from the entire experimental site with a soil core sample type cup auger $(0.10 \mathrm{~m} \times 0.40 \mathrm{~m}$ - cup diameter and length, respectively) from $0.00-0.20 \mathrm{~m}$ depth. The samples were mixed and a random subsample from each depth was collected, air-dried, sieved (2-mm), and stored at ambient temperature until analyses. The subsample was used for the determination of soil chemical attributes and granulometry prior to soil amendment sources application on October 9th, 2015. Soil chemical attributes were analysed according to Raij et al. [54] and granulometry followed Teixeira et al. [55]. Total $\mathrm{N}$ was determined by the semi-micro Kjeldahl method [56]. Silicon was determined after extraction in Ca chloride $\left(0.01 \mathrm{~mol} \mathrm{~L}^{-1}\right)$ according to the methodology of Korndörfer et al. [57] (Table 7).

Table 7. Soil chemical attributes and granulometry in $0-0.20 \mathrm{~m}$ depth before $\mathrm{Si}$ amendment source application in 2015.

\begin{tabular}{|c|c|c|}
\hline Soil Chemical Attributes & Unit & 0-0.20 m Layer \\
\hline Total N & $\mathrm{g} \mathrm{kg}^{-1}$ & 1.04 \\
\hline $\mathrm{P}($ resin $)$ & $\mathrm{mg} \mathrm{kg}^{-1}$ & 19 \\
\hline $\mathrm{S}\left(\mathrm{SO}_{4}\right)$ & $\mathrm{mg} \mathrm{kg}^{-1}$ & 10 \\
\hline Organic matter & $\mathrm{g} \mathrm{kg}^{-1}$ & 21 \\
\hline $\mathrm{pH}\left(\mathrm{CaCl}_{2}\right)$ & & 5.0 \\
\hline $\mathrm{K}$ & $\mathrm{mmol}_{\mathrm{C}} \mathrm{kg}^{-1}$ & 2.1 \\
\hline $\mathrm{Ca}$ & $\mathrm{mmol}_{\mathrm{C}} \mathrm{kg}^{-1}$ & 19.0 \\
\hline $\mathrm{Mg}$ & $\mathrm{mmol}_{\mathrm{C}} \mathrm{kg}^{-1}$ & 13.0 \\
\hline $\mathrm{H}+\mathrm{Al}$ & $\mathrm{mmol}_{\mathrm{C}} \mathrm{kg}^{-1}$ & 28.0 \\
\hline $\mathrm{Al}$ & $\mathrm{mmol}_{\mathrm{c}} \mathrm{kg}^{-1}$ & 1.0 \\
\hline B (hot water) & $\mathrm{mg} \mathrm{kg}^{-1}$ & 0.17 \\
\hline $\mathrm{Cu}(\mathrm{DTPA})$ & $\mathrm{mg} \mathrm{kg}^{-1}$ & 3.1 \\
\hline $\mathrm{Fe}$ (DTPA) & $\mathrm{mg} \mathrm{kg}^{-1}$ & 20.0 \\
\hline Mn (DTPA) & $\mathrm{mg} \mathrm{kg}^{-1}$ & 27.2 \\
\hline $\mathrm{Zn}$ (DTPA) & $\mathrm{mg} \mathrm{kg}^{-1}$ & 0.8 \\
\hline Cation exchange capacity ( $\mathrm{pH} 7.0$ ) & $\mathrm{mmol}_{\mathrm{C}} \mathrm{kg}^{-1}$ & 62.1 \\
\hline Base saturation & $\%$ & 55 \\
\hline Granulometry & & 0-0.20 m Layer \\
\hline Sand & $\mathrm{g} \mathrm{kg}^{-1}$ & 471 \\
\hline Silt & $\mathrm{g} \mathrm{kg}^{-1}$ & 90 \\
\hline Clay & $\mathrm{g} \mathrm{kg}^{-1}$ & 439 \\
\hline
\end{tabular}

$n=20$, DTPA $=$ diethylenetriaminepentaacetic acid.

The experimental area had been cultivated with annual leguminous and cereal crops for over 30 years. In addition, the area has been under no-tillage for the last 15 years. The crop sequence prior to the field trial was maize (2014), soybean (Glycine max (L.) Merr.) (2014/15), maize (2015), maize (2015/16), wheat (2016), maize (2016/17) and wheat (2017). The 2015 maize crop received the application of $180 \mathrm{~kg} \mathrm{~N} \mathrm{ha}^{-1}$ on the entire experimental site. From maize 2015/16 crop until wheat 2017 crop, specific rates of $\mathrm{Si}$ and N were performed in each plot. The maximum, average, and minimum temperatures and rainfall observed during the field trial are reported in Figure 5.

\subsection{Experimental Design and Treatments}

The experimental design was a randomized complete block design (RCBD), with four replicates arranged in a $2 \times 4$ full factorial scheme. The treatments comprised two soil amendment sources: (1) $\mathrm{Si}$ application (+Si) treatment: $\mathrm{Ca}$ and $\mathrm{Mg}$ silicate (one single product$10.5 \% \mathrm{Si}, 25 \% \mathrm{CaO}$, and $6 \% \mathrm{MgO}$, solubility of $0.095 \mathrm{~g} \mathrm{~L}^{-1}$ ) with an effective neutralizing power (ENP) of $88 \%$, and (2) absence of $\mathrm{Si}$ application $(-\mathrm{Si})$ : dolomitic limestone $(28 \%$ $\mathrm{CaO}$ and $20 \% \mathrm{MgO}$, solubility of $0.014 \mathrm{~g} \mathrm{~L}^{-1}$ ) with an ENP of $80 \%$; and four $\mathrm{N}$ levels, applied in side-dress $\mathrm{N}$ application: (1) control $\left(0 \mathrm{~kg} \mathrm{~N} \mathrm{ha}^{-1}\right)$, (2) low $\left(50 \mathrm{~kg} \mathrm{~N} \mathrm{ha}^{-1}\right)$, (3) medium $\left(100 \mathrm{~kg} \mathrm{~N} \mathrm{ha}^{-1}\right)$, and (4) high $\left(200 \mathrm{~kg} \mathrm{~N} \mathrm{ha}^{-1}\right)$ levels. These levels were selected 
based on previous studies with $\mathrm{N}$ management in maize and wheat crops under Brazilian tropical Savannah conditions [35]. The applied N source was urea (45\% of N) at six leaves completely unfolded (at V6 phenological stage) of maize and wheat tillering-decimal growth stage GS21 [58].

Wheat planting took place on the same plots of the preceding crop (maize) and the same plots were used for the entire duration of the study. The experimental plots were six maize rows of five meters spaced at a distance of $0.45 \mathrm{~m}$, when maize was cultivated $\left(13.5 \mathrm{~m}^{2}\right)$ and twelve wheat rows of five meters spaced at a distance of $0.17 \mathrm{~m}$, when wheat was cultivated $\left(10.2 \mathrm{~m}^{2}\right)$. The useful central area of the plot was considered as $10 \mathrm{~m}^{2}$ $(5 \mathrm{~m} \times 2 \mathrm{~m})$ and was used as reference point to plant maize and wheat.

Soil amendment sources (Si treatments) were broadcast applied at the rate of $1.76 \mathrm{Mg} \mathrm{ha}^{-1}$ for the silicate (equivalent to $185 \mathrm{~kg} \mathrm{Si} \mathrm{ha}^{-1}$ ) and $1.94 \mathrm{Mg} \mathrm{ha}^{-1}$ for the limestone 30 days before planting maize $(2015 / 16)$ in a one-time, single application, without reapplication in subsequent years. No incorporation was performed as the area was under no-tillage. The amount of lime applied was based on the initial soil analysis and the amount needed to increase the base saturation (V) to $80 \%$ based on the following Equation (1):

$$
\mathrm{SAN}=\frac{\mathrm{CEC}(\mathrm{V} 2-\mathrm{V} 1)}{10 \times \mathrm{ENP}}
$$

where SAN = Soil amendment needed, in $\mathrm{Mg}$ ha ${ }^{1} ; \mathrm{CEC}=$ cation exchange capacity; $\mathrm{V} 2$ = base saturation to be achieved; V1 = current base saturation and ENP = effective neutralizing power.

\subsection{Maize and Wheat Management}

A simple maize hybrid DOW 2B710 was sown in both cultivations (2015/16 and 2016/17) at a density of 7.3 viable seeds $\mathrm{m}^{-2}$ with a no-till drill. At maize sowing, basal fertilization application was performed for all treatments with $375 \mathrm{~kg} \mathrm{ha}^{-1}$ of granular fertilizer 08-28-16 $\left(\mathrm{N}-\mathrm{P}_{2} \mathrm{O}_{5}-\mathrm{K}_{2} \mathrm{O}\right)$ in the sowing furrows based on the soil analysis and maize crop requirements [59]. As we mentioned before, $\mathrm{N}$ side-dressing ( $\mathrm{N}$ application levels) was manually applied at V6 phenological stage to evenly distribute the fertilizer on soil surface without incorporation. Maize was cultivated during 13 November 2015 to 15 March 2016 (harvested 116 days after emergence) and 11 November 2016 to 21 March 2017 (harvested 125 days after emergence) in 2015/16 and 2016/17 cropping season, respectively. Weeds were controlled using pre and post-emergence herbicides, and insects were controlled using best management practices in maize. When necessary, maize crop was irrigated with supplementary irrigation through a center pivot sprinkling system (water depth of $14 \mathrm{~mm}$ ).

The wheat cultivar CD 1104 was sown in both cultivated years (2016 and 2017) at a density of 412 viable seeds $\mathrm{m}^{-2}$ with a no-till drill. Additionally, basal fertilization application was performed at sowing for all treatments with $275 \mathrm{~kg} \mathrm{ha}^{-1}$ of the granular fertilizer 08-28-16 $\left(\mathrm{N}-\mathrm{P}_{2} \mathrm{O}_{5}-\mathrm{K}_{2} \mathrm{O}\right)$ in the sowing furrows based on the soil analysis and crop requirements [59]. Nitrogen application in side-dressing ( $\mathrm{N}$ application levels) was performed manually to evenly distribute the fertilizer on the soil surface without incorporation during wheat tillering. The crop was irrigated with supplementary irrigation using a center pivot sprinkling system (water depth of $14 \mathrm{~mm}$ ) based on the crop moisture requirement. The crop was cultivated during 3 May 2016 to 8 September 2016 (harvested 120 days after emergence) and 10 May 2017 to 12 September 2017 (harvested 117 days after emergence). Weeds were controlled using pre- and post-emergence herbicides, and insects were controlled using best management practices for wheat.

\subsection{Samplings and Analysis}

Five maize plants and wheat plants from an area of $0.17 \mathrm{~m}^{2}(0.17 \mathrm{~m}$-width of the row $\times 1.0 \mathrm{~m}$ ) were harvested at ground level during flowering for shoot collection. At the same time, a side trench of approximately $0.50 \mathrm{~m}$ depth was dug for root collection and then washed with deionized water. In addition, leaf chlorophyll index (for maize 
and wheat), was determined indirectly by collecting readings on 20 maize ear leaves and 30 wheat flag leaves and when plants reached the flowering stage, using a portable nondestructive ClorofiLOG ${ }^{\circledR}$ meter (model CFL-1030, Falker, Porto Alegre, Brazil). The shoots and roots were dried for $90 \mathrm{~h}$ in a forced-air oven at $60^{\circ} \mathrm{C}$. Then, the shoots and roots biomass $\left(\mathrm{kg} \mathrm{ha}^{-1}\right)$ were weighed. The Si concentration was determined following Silva [60] and total $\mathrm{N}$ analysis followed the methodology proposed by Malavolta et al. [61]. Silicon were quantified in an Ultraviolet-visible spectroscopy spectrophotometer (UVVIS-Model Varian Cary-50, Varian, Victoria, Australia). Nitrogen was distilled by semimicro Kjeldahl method and determined by titration with $\mathrm{HCl} 0.05 \mathrm{~N}$. The inorganic $\mathrm{N}$ concentration ( ${\mathrm{N}-\mathrm{NO}_{3}}^{-}$and $\mathrm{N}-\mathrm{NH}_{4}{ }^{+}$) in plant tissues was determined following Tedesco et al. [62]. Briefly, $1 \mathrm{~g}$ of plant tissue was extracted with $1 \mathrm{~mol} \mathrm{KCl} \mathrm{L}^{-1}$ (ratio of 1:15, plant tissue: solution, $w / v)$, distilled with $\mathrm{MgO}\left(\mathrm{N}_{-} \mathrm{NH}_{4}{ }^{+}\right)$and Devarda's alloy and titrated with $2.5 \mathrm{mmol} \mathrm{H}_{2} \mathrm{SO}_{4} \mathrm{~L}^{-1}\left(\mathrm{~N}_{-} \mathrm{NO}_{3}{ }^{-}\right)$. The accumulated $\mathrm{Si}$, total $\mathrm{N}, \mathrm{N}_{-} \mathrm{NH}_{4}{ }^{+}$and $\mathrm{N}^{-\mathrm{NO}_{3}}{ }^{-}$in shoot and root were obtained by the product of $\mathrm{Si}$, total $\mathrm{N}$ and inorganic $\mathrm{N}$ concentrations in tissue and produced biomass. Grain yield was determined by spike collection from the useful lines of each maize and wheat plots. After mechanical harvest, the grains were weighted ( $\mathrm{kg} \mathrm{ha}^{-1}$ with $13 \%$ moisture content in wet basis). Grain Si and N accumulation were determined following the same procedures as shoot and root $\mathrm{Si}$ and $\mathrm{N}$ accumulation. Agronomic efficiency of applied N-fertilizer (AE) was calculated following Fageria et al. [63] methodology presented in Equation (2).

$$
\mathrm{AE}\left(\mathrm{kg} \text { grain } \mathrm{kg} \mathrm{N} \text { applied }{ }^{-1}\right)=(\text { grain yield at } \mathrm{Nx}-\text { grain yield at } \mathrm{N} 0) \div \mathrm{N} \text { level applied }
$$

where $\mathrm{Nx}$ is the $\mathrm{N}$ level applied and $\mathrm{N} 0$ is the control treatment (without $\mathrm{N}$ applied in side-dressing).

\subsection{Statistical Analysis}

All data were initially tested for Levene's homoscedasticity test $(p \leq 0.05)$ and normality using Shapiro and Wilk test, which showed the data to be normally distributed $(W \geq 0.90)$. Data were submitted to analysis of variance ( $F$ test) using repeated measures (cropping seasons (maize and wheat, separately) as the repeated variable) and a compound symmetry model for the covariance parameters. When a significant main effect or interaction was observed by the $F$ test $(p \leq 0.05)$, the Tukey test $(p \leq 0.05)$ was used for comparison of means of $\mathrm{Si}$ application, $\mathrm{N}$ levels, cropping seasons and their interactions using the ExpDes package. To identify dependent variables directly related to Si accumulation in maize and wheat plants, a Pearson correlation analysis $(p \leq 0.05)$ was performed. To create a heatmap, the corrplot package was used, using the "cor" and "cor.mtest" functions to calculate the coefficients and $p$-value matrices. Asterisks were added to the heatmap cells to the identification of significant correlations. All the statistical analysis was performed using R software [64].

\section{Conclusions}

Silicon amendment application enhanced leaf chlorophyll index, agronomic efficiency and N-uptake in maize and wheat plants, benefiting shoot and root development and leading to a higher grain yield (an increase of 5.2 and $7.6 \%$, respectively). We verified that it would be possible to reduce $\mathrm{N}$ fertilization in maize from $180-185$ to $100 \mathrm{~kg} \mathrm{~N}^{-1}$ while maintaining similar grain yield with Si application. Additionally, when Si application was performed, it would be possible to reduce $\mathrm{N}$ fertilization in wheat from $195-200$ to $100 \mathrm{~kg} \mathrm{~N} \mathrm{ha}^{-1}$. Therefore, in view of a high probability of a positive response to maize-wheat cropping sequence even associated with different $\mathrm{N}$ application levels, the $\mathrm{Si}$ amendment application could be a key technology for improving plant-soil N-management, especially in Si accumulator crops and leading to a more sustainable cereal production under tropical conditions. 
Author Contributions: F.S.G. and M.C.M.T.F., conceptualized the project, investigated, collected, and analyzed the original draft of data; M.C.M.T.F., project administration and supervision; F.S.G., graph editing; P.H.P., S.B., J.L., and M.C.M.T.F., review and editing; W.L.R., G.C.F., E.H.M.B., J.M.K.S., and A.J., field and lab help. All authors have read and agreed to the published version of the manuscript.

Funding: This research was funded by Fundação de Amparo à Pesquisa do Estado de São PauloFAPESP, grant number 2017/06002-6 and Conselho Nacional de Desenvolvimento Científico e Tecnológico-CNPq, award number 312359/2017-9.

Institutional Review Board Statement: Not applicable.

Informed Consent Statement: Not applicable.

Data Availability Statement: All data generated or analyzed during this study are included in this published article.

Acknowledgments: The authors would like to thank FAPESP and CNPq for the funding and overall support.

Conflicts of Interest: The authors declare no conflict of interest.

\section{Appendix A}

Table A1. Summary of statistical analysis ( $p$-values) for maize leaf chlorophyll index (LCI) root and shoot nitrate $\left(\mathrm{N}^{-\mathrm{NO}}{ }_{3}{ }^{-}\right)$, ammonium $\left(\mathrm{N}_{-} \mathrm{NH}_{4}{ }^{+}\right)$, total $\mathrm{N}$ and $\mathrm{Si}$ accumulation, grain total $\mathrm{N}$ and $\mathrm{Si}$ accumulation, root and shoot biomass, grain yield and agronomic efficiency (AE) affected by Si application, $\mathrm{N}$ level, year and their interactions.

\begin{tabular}{|c|c|c|c|c|c|c|c|c|}
\hline Variable & LCI & $\begin{array}{c}\text { Root } \\
\mathrm{N}-\mathrm{NO}_{3}-\end{array}$ & $\underset{\mathrm{N}_{-} \mathrm{NH}_{4}}{\text { Root }}$ & $\begin{array}{c}\text { Root Total } \\
\mathbf{N}\end{array}$ & Root Si & $\begin{array}{c}\text { Shoot } \\
\mathrm{N}^{-\mathrm{NO}_{3}}{ }^{-}\end{array}$ & $\begin{array}{c}\text { Shoot } \\
\mathrm{N}^{-\mathrm{NH}_{4}}{ }^{+}\end{array}$ & $\begin{array}{c}\text { Shoot Total } \\
\text { N }\end{array}$ \\
\hline Silicon application (SA) & 0.001 & 0.085 & 0.001 & 0.630 & 0.001 & 0.002 & 0.002 & 0.001 \\
\hline $\mathrm{N}$ level $(\mathrm{N})$ & 0.001 & 0.001 & 0.001 & 0.001 & 0.001 & 0.001 & 0.001 & 0.001 \\
\hline Year $(Y)$ & 0.288 & 0.001 & 0.001 & 0.001 & 0.103 & 0.733 & 0.002 & 0.001 \\
\hline $\mathrm{SA} \times \mathrm{N}$ & 0.282 & 0.002 & 0.001 & 0.174 & 0.060 & 0.116 & 0.340 & 0.014 \\
\hline$S A \times Y$ & 0.815 & 0.129 & 0.001 & 0.950 & 0.426 & 0.254 & 0.081 & 0.710 \\
\hline $\mathrm{N} \times \mathrm{Y}$ & 0.103 & 0.880 & 0.064 & 0.343 & 0.292 & 0.158 & 0.120 & 0.156 \\
\hline $\mathrm{SA} \times \mathrm{N} \times \mathrm{Y}$ & 0.213 & 0.111 & 0.304 & 0.217 & 0.127 & 0.337 & 0.111 & 0.343 \\
\hline Variable & Shoot Si & $\begin{array}{c}\text { Grain Total } \\
\mathbf{N}\end{array}$ & Grain Si & $\begin{array}{c}\text { Root } \\
\text { Biomass }\end{array}$ & $\begin{array}{c}\text { Shoot } \\
\text { Biomass }\end{array}$ & Grain Yield & \multicolumn{2}{|r|}{$\mathrm{AE}$} \\
\hline Silicon application (SA) & 0.001 & 0.001 & 0.001 & 0.196 & 0.003 & 0.002 & \multicolumn{2}{|r|}{0.003} \\
\hline $\mathrm{N}$ level (N) & 0.001 & 0.001 & 0.001 & 0.001 & 0.001 & 0.001 & \multicolumn{2}{|r|}{0.001} \\
\hline Year $(Y)$ & 0.001 & 0.001 & 0.001 & 0.001 & 0.001 & 0.001 & \multicolumn{2}{|r|}{0.676} \\
\hline $\mathrm{SA} \times \mathrm{N}$ & 0.289 & 0.002 & 0.001 & 0.002 & 0.236 & 0.141 & \multicolumn{2}{|r|}{0.031} \\
\hline$S A \times Y$ & 0.131 & 0.001 & 0.001 & 0.934 & 0.839 & 0.292 & \multicolumn{2}{|r|}{0.239} \\
\hline $\mathrm{N} \times \mathrm{Y}$ & 0.060 & 0.071 & 0.138 & 0.854 & 0.570 & 0.145 & \multicolumn{2}{|r|}{0.098} \\
\hline $\mathrm{SA} \times \mathrm{N} \times \mathrm{Y}$ & 0.077 & 0.180 & 0.260 & 0.309 & 0.511 & 0.208 & \multicolumn{2}{|r|}{0.319} \\
\hline
\end{tabular}

\section{Appendix B}

Table A2. Summary of statistical analysis ( $p$-values) for wheat leaf chlorophyll index (LCI) root and shoot nitrate $\left(\mathrm{N}^{-\mathrm{NO}}{ }_{3}{ }^{-}\right)$, ammonium $\left(\mathrm{N}^{-} \mathrm{NH}_{4}{ }^{+}\right)$, total $\mathrm{N}$ and $\mathrm{Si}$ accumulation, grain total $\mathrm{N}$ and $\mathrm{Si}$ accumulation, root and shoot biomass, grain yield and agronomic efficiency (AE) affected by Si application, $\mathrm{N}$ level, year and their interactions.

\begin{tabular}{|c|c|c|c|c|c|c|c|c|}
\hline Variable & LCI & $\begin{array}{c}\text { Root } \\
\mathrm{N}^{-\mathrm{NO}_{3}}-\end{array}$ & $\begin{array}{c}\text { Root } \\
\mathrm{N}_{-\mathrm{NH}_{4}}^{+}\end{array}$ & $\begin{array}{c}\text { Root Total } \\
\mathbf{N}\end{array}$ & Root Si & $\begin{array}{c}\text { Shoot } \\
\mathrm{N}^{-\mathrm{NO}_{3}}-\end{array}$ & $\begin{array}{c}\text { Shoot } \\
\mathrm{N}^{-\mathrm{NH}_{4}}{ }^{+}\end{array}$ & $\begin{array}{c}\text { Shoot Total } \\
\mathbf{N}\end{array}$ \\
\hline Silicon application (SA) & 0.001 & 0.001 & 0.002 & 0.246 & 0.001 & 0.001 & 0.002 & 0.003 \\
\hline $\mathrm{N}$ level $(\mathrm{N})$ & 0.001 & 0.001 & 0.037 & 0.905 & 0.001 & 0.001 & 0.001 & 0.001 \\
\hline Year $(Y)$ & 0.001 & 0.001 & 0.007 & 0.001 & 0.001 & 0.002 & 0.026 & 0.594 \\
\hline $\mathrm{SA} \times \mathrm{N}$ & 0.033 & 0.078 & 0.783 & 0.622 & 0.001 & 0.264 & 0.167 & 0.193 \\
\hline$S A \times Y$ & 0.001 & 0.689 & 0.051 & 0.923 & 0.001 & 0.363 & 0.073 & 0.317 \\
\hline $\mathrm{N} \times \mathrm{Y}$ & 0.059 & 0.109 & 0.446 & 0.072 & 0.231 & 0.606 & 0.303 & 0.511 \\
\hline $\mathrm{SA} \times \mathrm{N} \times \mathrm{Y}$ & 0.184 & 0.595 & 0.993 & 0.637 & 0.615 & 0.934 & 0.224 & 0.442 \\
\hline
\end{tabular}


Table A2. Cont.

\begin{tabular}{lcccccc}
\hline Variable & Shoot Si & $\begin{array}{c}\text { Grain Total } \\
\text { N }\end{array}$ & Grain Si & $\begin{array}{c}\text { Root } \\
\text { Biomass }\end{array}$ & $\begin{array}{c}\text { Shoot } \\
\text { Biomass }\end{array}$ & Grain Yield \\
\hline Silicon application (SA) & 0.001 & 0.001 & 0.001 & 0.001 & 0.001 & 0.002 \\
N level (N) & 0.001 & 0.011 & 0.754 & 0.001 & 0.004 & 0.001 \\
Year (Y) & 0.001 & 0.007 & 0.001 & 0.001 & 0.001 & 0.001 \\
SA $\times$ N & 0.592 & 0.869 & 0.076 & 0.002 & 0.997 & 0.415 \\
SA $\times$ Y & 0.056 & 0.675 & 0.333 & 0.003 & 0.081 & 0.576 \\
N $\times$ Y & 0.464 & 0.764 & 0.142 & 0.194 & 0.123 & 0.155 \\
SA $\times$ N $\times$ Y & 0.460 & 0.072 & 0.420 & 0.287 & 0.417 & 0.127 \\
\hline
\end{tabular}

\section{Appendix C}

Linear interpolation is a method of curve fitting using linear polynomials to construct new data points within the range of a discrete set of known data points.

If the two known points are given by the coordinates $(x 0, y 0)$ and $(x 1, y 1)$ the linear interpolant is the straight line between these points. For a value $\mathrm{x}$ in the interval $(x 0, x 1)$, the value $y$ along the straight line is given from the equation of slopes:

$$
\frac{y-y 0}{y 1-y 0}=\frac{x-x 0}{x 1-x 0}
$$

where, $y$ refers to maize and wheat grain yield at $180-185 \mathrm{~kg} \mathrm{~N}^{-1}$ without Si application (maize) and 195-200 kg N ha ${ }^{-1}$ without Si application (wheat); $y 0$ refers to maize and wheat grain yield at $100 \mathrm{~kg} \mathrm{~N}^{-1}$ without Si application; $y 1$ refers to maize and wheat grain yield at $200 \mathrm{~kg} \mathrm{~N}$ ha $^{-1}$ without Si application; $x$ refers to $180-185 \mathrm{~kg} \mathrm{~N}^{-1}$ (maize) and $195-200 \mathrm{~kg} \mathrm{~N} \mathrm{ha}^{-1}$ (wheat); $x 0$ refers to $100 \mathrm{~kg} \mathrm{~N}$ ha $^{-1}$ and $x 1$ refers to $200 \mathrm{~kg} \mathrm{~N} \mathrm{ha}^{-1}$.

Maize grain yield

$$
\frac{y-9575}{10388-9575}=\frac{180 \text { or } 185-100}{200-100}
$$

Therefore, the calculated $y$ for $180-185 \mathrm{~kg} \mathrm{~N}^{-1}$ without Si application $=10223$ $10264 \mathrm{~kg} \mathrm{ha}^{-1}$.

Wheat grain yield

$$
\frac{y-3996}{4405-3996}=\frac{195-100}{200-100}
$$

Therefore, the calculated $y$ for $195 \mathrm{~kg} \mathrm{~N} \mathrm{ha}^{-1}$ without Si application $=4385 \mathrm{~kg} \mathrm{ha}^{-1}$. The $y$ value for $200 \mathrm{~kg} \mathrm{~N} \mathrm{ha}^{-1}$ was already obtained (high $\mathrm{N}$ level without Si application) = $4405 \mathrm{~kg} \mathrm{ha}^{-1}$.

\section{References}

1. Luyckx, M.; Hausman, J.-F.; Lutts, S.; Guerriero, G. Silicon and Plants: Current Knowledge and Technological Perspectives. Front. Plant Sci. 2017, 8, 411. [CrossRef]

2. Wang, M.; Gao, L.; Dong, S.; Sun, Y.; Shen, Q.; Guo, S. Role of Silicon on Plant-Pathogen Interactions. Front. Plant Sci. 2017, 8, 701. [CrossRef] [PubMed]

3. Haynes, R.J. What effect does liming have on silicon availability in agricultural soils? Geoderma 2019, 337, 375-383. [CrossRef]

4. Galindo, F.S.; Buzetti, S.; Rodrigues, W.L.; Boleta, E.H.M.; Silva, V.M.; Tavanti, R.F.R.; Fernandes, G.C.; Biagini, A.L.C.; Rosa, P.A.L.; Teixeira Filho, M.C.M. Inoculation of Azospirillum brasilense associated with silicon as a liming source to improve nitrogen fertilization in wheat crops. Sci. Rep. 2020, 10, 6160. [CrossRef] [PubMed]

5. Galindo, F.S.; Pagliari, P.H.; Buzetti, S.; Rodrigues, W.L.; Santini, J.M.K.; Boleta, E.; Rosa, P.A.L.; Nogueira, T.A.R.; Lazarini, E.; Filho, M.C.M.T. Can silicon applied to correct soil acidity in combination with Azospirillum brasilense inoculation improve nitrogen use efficiency in maize? PLoS ONE 2020, 15, e0230954. [CrossRef]

6. Cuong, T.X.; Ullah, H.; Datta, A.; Hanh, T.C. Effects of Silicon-Based Fertilizer on Growth, Yield and Nutrient Uptake of Rice in Tropical Zone of Vietnam. Rice Sci. 2017, 24, 283-290. [CrossRef]

7. Keeping, M.G.; Miles, N.; Rutherford, R.S. Liming an Acid Soil Treated With Diverse Silicon Sources: Effects on Silicon Uptake by Sugarcane (Saccharum Spp. Hybrids). J. Plant Nutr. 2017, 40, 1417-1436. [CrossRef]

8. Schaller, J.; Turner, B.L.; Weissflog, A.; Pino, D.; Bielnicka, A.W.; Engelbrecht, B.M.J. Silicon in tropical forests: Large variation across soils and leaves suggests ecological significance. Biogeochemistry 2018, 140, 161-174. [CrossRef] 
9. Caubet, M.; Cornu, S.; Saby, N.P.A.; Meunier, J.-D. Agriculture increases the bioavailability of silicon, a beneficial element for crop, in temperate soils. Sci. Rep. 2020, 10, 1-11. [CrossRef]

10. Vandevenne, F.; Struyf, E.; Clymans, W.; Meire, P. Agricultural silica harvest: Have humans created a new loop in the global silica cycle? Front. Ecol. Environ. 2012, 10, 243-248. [CrossRef]

11. Schaller, J.; Puppe, D.; Kaczorek, D.; Ellerbrock, R.; Sommer, M. Silicon Cycling in Soils Revisited. Plants 2021, 10, 295. [CrossRef] [PubMed]

12. Guntzer, F.; Keller, C.; Meunier, J.-D. Benefits of plant silicon for crops: A review. Agron. Sustain. Dev. 2012, 32, 201-213. [CrossRef]

13. Bakhat, H.F.; Bibi, N.; Zia, Z.; Abbas, S.; Hammad, H.M.; Fahad, S.; Ashraf, M.R.; Shah, G.M.; Rabbani, F.; Saeed, S. Silicon mitigates biotic stresses in crop plants: A review. Crop. Prot. 2018, 104, 21-34. [CrossRef]

14. Liang, Y.; Nikolic, M.; Belanger, R.R.; Gong, H.; Song, A. Silicon Biogeochemistry and Bioavailability in Soil. In Silicon in Agriculture; Springer Science and Business Media: Berlin, Germany, 2015; pp. 45-68.

15. Linden, C.V.; Delvaux, B. The weathering stage of tropical soils affects the soil-plant cycle of silicon, but depending on land use. Geoderma 2019, 351, 209-220. [CrossRef]

16. Mohanty, S.; Nayak, A.K.; Swain, C.K.; Dhal, B.; Kumar, A.; Tripathi, R.; Shahid, M.; Lal, B.; Gautam, P.; Dash, G.K.; et al. Silicon enhances yield and nitrogen use efficiency of tropical low land rice. Agron. J. 2019, 112, 758-771. [CrossRef]

17. Crusciol, C.A.; Artigiani, A.C.; Arf, O.; Filho, A.C.C.; Soratto, R.; Nascente, A.S.; Alvarez, R.C. Soil fertility, plant nutrition, and grain yield of upland rice affected by surface application of lime, silicate, and phosphogypsum in a tropical no-till system. Catena 2016, 137, 87-99. [CrossRef]

18. Crusciol, C.A.; Artigiani, A.C.; Arf, O.; Filho, A.C.C.; Soratto, R.P.; Nascente, A.S.; Alvarez, R.C. Surface Application of Lime-Silicate-Phosphogypsum Mixtures for Improving Tropical Soil Properties and Irrigated Common Bean Yield. Soil Sci. Soc. Am. J. 2016, 80, 930-942. [CrossRef]

19. Neu, S.; Schaller, J.; Dudel, E.G. Silicon availability modifies nutrient use efficiency and content, C:N:P stoichiometry, and productivity of winter wheat (Triticum aestivum L.). Sci. Rep. 2017, 7, 40829. [CrossRef]

20. Xu, D.; Gao, X.; Gao, T.; Mou, J.; Li, J.; Bu, H.; Zhang, R.; Li, Q. Interactive effects of nitrogen and silicon addition on growth of five common plant species and structure of plant community in alpine meadow. Catena 2018, 169, 80-89. [CrossRef]

21. Hurtado, A.C.; Chiconato, D.A.; Prado, R.D.M.; Junior, G.D.S.S.; Felisberto, G. Silicon attenuates sodium toxicity by improving nutritional efficiency in sorghum and sunflower plants. Plant Physiol. Biochem. 2019, 142, 224-233. [CrossRef] [PubMed]

22. Haddad, C.; Arkoun, M.; Jamois, F.; Schwarzenberg, A.; Yvin, J.-C.; Etienne, P.; Laîné, P. Silicon Promotes Growth of Brassica napus L. and Delays Leaf Senescence Induced by Nitrogen Starvation. Front. Plant Sci. 2018, 9, 516. [CrossRef]

23. Haddad, C.; Trouverie, J.; Arkoun, M.; Yvin, J.-C.; Caïus, J.; Brunaud, V.; Laîné, P.; Etienne, P. Silicon supply affects the root transcriptome of Brassica napus L. Planta 2019, 249, 1645-1651. [CrossRef]

24. Matichenkov, V.V.; Bocharnikova, E.A. The relationship between silicon and soil physical and chemical properties. In Studies in Plant Science; Datnoff, L.E., Snyder, G.H., Korndorfer, G.H., Eds.; Elsevier: Amsterdam, The Netherlands, 2001; Volume 8, pp. 209-219.

25. Siam, H.S.; Abd El-Moez, M.R.; Holah, S.S.; Abou Zeid, S.T. Effect of silicon addition to different fertilizer on yield of rice (Oryza sativa L.) plants. I-Macro nutrients by different rice parts. Middle East J. Appl. Sci. 2018, 8, 177-190.

26. Rangaraj, S.; Gopalu, K.; Rathinam, Y.; Periasamy, P.; Venkatachalam, R.; Narayanasamy, K.; Suriyaprabha, R.; Karunakaran, G.; Yuvakkumar, R.; Prabu, P.; et al. Effect of silica nanoparticles on microbial biomass and silica availability in maize rhizosphere. Biotechnol. Appl. Biochem. 2014, 61, 668-675. [CrossRef] [PubMed]

27. Singh, A.K.; Singh, R.; Singh, K. Growth, yield, and economics of rice (Oryza sativa) as influenced by level and time of silicon application. Ind. J. Agron. 2005, 50, 190-193.

28. Laîné, P.; Haddad, C.; Arkoun, M.; Yvin, J.-C.; Etienne, P. Silicon Promotes Agronomic Performance in Brassica napus Cultivated under Field Conditions with Two Nitrogen Fertilizer Inputs. Plants 2019, 8, 137. [CrossRef] [PubMed]

29. Xu, A.; Li, L.; Xie, J.; Wang, X.; Coulter, J.A.; Liu, C.; Wang, L. Effect of Long-Term Nitrogen Addition on Wheat Yield, Nitrogen Use Efficiency, and Residual Soil Nitrate in a Semiarid Area of the Loess Plateau of China. Sustainability 2020, 12, 1735. [CrossRef]

30. Sainju, U.M.; Ghimire, R.; Pradhan, G. Nitrogen Fertilization I: Impact on Crop, Soil, and Environment. In Advances in Biology and Ecology of Nitrogen Fixation; IntechOpen: London, UK, 2020.

31. Galindo, F.; Filho, M.C.M.T.; Buzetti, S.; Pagliari, P.H.; Santini, J.M.K.; Alves, C.J.; Megda, M.; Nogueira, T.A.R.; Andreotti, M.; Arf, O. Maize Yield Response to Nitrogen Rates and Sources Associated with Azospirillum brasilense. Agron. J. 2019, 111, 1985-1997. [CrossRef]

32. Galindo, F.S.; Filho, M.C.M.T.; Buzetti, S.; Santini, J.M.K.; Alves, C.J.; Ludkiewicz, M.G.Z. Wheat yield in the Cerrado as affected by nitrogen fertilization and inoculation with Azospirillum brasilense. Pesqui. Agropecuária Bras. 2017, 52, 794-805. [CrossRef]

33. Brusamarello-Santos, L.C.; Gilard, F.; Brulé, L.; Quilleré, I.; Gourion, B.; Ratet, P.; De Souza, E.M.; Lea, P.J.; Hirel, B. Metabolic profiling of two maize (Zea mays L.) inbred lines inoculated with the nitrogen fixing plant-interacting bacteria Herbaspirillum seropedicae and Azospirillum brasilense. PLOS ONE 2017, 12, e0174576. [CrossRef]

34. Tsujimoto, Y.; Rakotoson, T.; Tanaka, A.; Saito, K. Challenges and opportunities for improving N use efficiency for rice production in sub-Saharan Africa. Plant Prod. Sci. 2019, 22, 413-427. [CrossRef] 
35. Galindo, F.S.; da Silva, E.C.; Pagliari, P.H.; Fernandes, G.C.; Rodrigues, W.L.; Biagini, A.L.C.; Baratella, E.B.; Júnior, C.A.D.S.; Neto, M.J.M.; Muraoka, T.; et al. Nitrogen use efficiency and recovery in a wheat-corn rotation under tropical savannah conditions. Nutr. Cycl. Agroecosystems 2021, 119, 1-15. [CrossRef]

36. Isa, M.; Bai, S.; Yokoyama, T.; Ma, J.F.; Ishibashi, Y.; Yuasa, T.; Iwaya-Inoue, M. Silicon enhances growth independent of silica deposition in a low-Silica rice mutant, 1si1. Plant Soil 2010, 331, 361-375. [CrossRef]

37. McLarnon, E.; McQueen-Mason, S.; Lenk, I.; Hartley, S.E. Evidence for Active Uptake and Deposition of Si-based Defenses in Tall Fescue. Front. Plant Sci. 2017, 8, 1199. [CrossRef]

38. Walsh, O.S.; Shafian, S.; McClintick-Chess, J.R.; Belmont, K.M.; Blanscet, S.M. Potential of Silicon Amendment for Improved Wheat Production. Plants 2018, 7, 26. [CrossRef] [PubMed]

39. Ma, J.F.; Yamaji, N. Functions and transport of silicon in plants. Cell. Mol. Life Sci. 2008, 65, 3049-3057. [CrossRef] [PubMed]

40. Feng, J.; Yamaji, N.; Mitani-Ueno, N. Transport of silicon from roots to panicles in plants. Proc. Jpn. Acad. Ser. B 2011, 87, 377-385. [CrossRef]

41. Meena, V.D.; Dotaniya, M.L.; Coumar, V.; Rajendiran, S.; Ajay; Kundu, S.S.; Rao, A.S. A Case for Silicon Fertilization to Improve Crop Yields in Tropical Soils. Proc. Natl. Acad. Sci. India Sect. B Boil. Sci. 2014, 84, 505-518. [CrossRef]

42. Tubana, B.S.; Babu, T.; Datnoff, L.E. A Review of Silicon in Soils and Plants and Its Role in US Agriculture. Soil Sci. 2016, 181, 393-411. [CrossRef]

43. Gong, H.; Chen, K. The regulatory role of silicon on water relations, photosynthetic gas exchange, and carboxylation activities of wheat leaves in field drought conditions. Acta Physiol. Plant. 2012, 34, 1589-1594. [CrossRef]

44. de Camargo, M.S.; Bezerra, B.K.L.; Vitti, A.C.; Silva, M.A.; Oliveira, A.L. Silicon fertilization reduces the deleterious effects of water deficit in sugarcane. J. soil Sci. Plant Nutr. 2017, 17, 99-111. [CrossRef]

45. Araújo, M.U.P.; Rios, J.A.; Silva, E.T.; Rodrigues, F. Ávila Silicon Alleviates Changes in the Source-Sink Relationship of Wheat Plants Infected by Pyricularia oryzae. Phytopathology 2019, 109, 1129-1140. [CrossRef]

46. Vega, I.; Nikolic, M.; Pontigo, S.; Godoy, K.; Mora, M.D.L.L.; Cartes, P. Silicon Improves the Production of High Antioxidant or Structural Phenolic Compounds in Barley Cultivars under Aluminum Stress. Agronomy 2019, 9, 388. [CrossRef]

47. Hajiboland, R.; Moradtalab, N.; Eshaghi, Z.; Feizy, J. Effect of silicon supplementation on growth and metabolism of strawberry plants at three developmental stages. N. Z. J. Crop. Hortic. Sci. 2018, 46, 144-161. [CrossRef]

48. Amin, M.; Ahmad, R.; Ali, A.; Hussain, I.; Mahmood, R.; Aslam, M.; Lee, D.J. Influence of Silicon Fertilization on Maize Performance Under Limited Water Supply. Silicon 2018, 10, 177-183. [CrossRef]

49. Artyszak, A. Effect of Silicon Fertilization on Crop Yield Quantity and Quality-A Literature Review in Europe. Plants 2018, 7, 54. [CrossRef]

50. Etesami, H.; Jeong, B.R. Silicon (Si): Review and future prospects on the action mechanisms in alleviating biotic and abiotic stresses in plants. Ecotoxicol. Environ. Saf. 2018, 147, 881-896. [CrossRef]

51. Bhat, J.A.; Shivaraj, S.M.; Singh, P.; Navadagi, D.B.; Tripathi, D.K.; Dash, P.K.; Solanke, A.U.; Sonah, H.; Deshmukh, R. Role of Silicon in Mitigation of Heavy Metal Stresses in Crop Plants. Plants 2019, 8, 71. [CrossRef]

52. de Camargo, M.S.; Bezerra, B.K.L.; Holanda, L.A.; Oliveira, A.L.; Vitti, A.C.; Silva, M.A. Silicon Fertilization Improves Physiological Responses in Sugarcane Cultivars Grown Under Water Deficit. J. Soil Sci. Plant Nutr. 2019, 19, 81-91. [CrossRef]

53. Smith, D.W. Soil Survey Staff: Keys to Soil Taxonomy, 12th ed.; USDA; Natural Resources Conservation Service: Washington, DC, USA, 2014

54. Raij, B.V.; Andrade, J.C.; Cantarella, H.; Quaggio, J.A. Chemical Analysis for Fertility Evaluation of Tropical Soils; IAC: Campinas, Brazil, 2001; p. 285. (In Portuguese)

55. Teixeira, P.C.; Donagemma, G.K.; Fontana, A.; Teixeira, W.G. Manual of Soil Analysis Methods; Centro nacional de pesquisa de solos, Embrapa: Rio de Janeiro, Brazil, 2017; p. 575. (In Portuguese)

56. Bremner, J.M.; Breitenbeck, G.A. A simple method for determination of ammonium in semimicro-Kjeldahl analysis of soils and plant materials using a block digester 1. Commun. Soil Sci. Plant Anal. 1983, 14, 905-913. [CrossRef]

57. Korndörfer, G.H.; Pereira, H.S.; Nolla, A. Silicon Analysis; Soil, Plant and Fertilizer; (Boletim Técnico, 2); GPSi/ICIAG/UFU: Uberlândia, Brazil, 2004; 50p. (In Portuguese)

58. Zadoks, J.C.; Chang, T.T.; Konzak, C.F. A decimal code for the growth stages of cereals. Weed Res. 1974, 14, 415-421. [CrossRef]

59. Cantarella, H.; Raij, B.V.; Camargo, C.E.O. Cereals. In Liming and Fertilization Recommendations for the State of São Paulo; Raij, B.V., Cantarella, H., Quaggio, J.A., Furlani, A.M.C., Eds.; Instituto Agronômico de Campinas: Campinas, Brazil, 1997; 285p. (In Portuguese)

60. da Silva, F.C. Manual of Chemical Analyzes of Soils, Plants and Fertilizers, 2nd ed.; Embrapa Informação Tecnológica: Brasília, DF, Brazil; Embrapa Solos: Rio de Janeiro, Brazil, 2009; 627p. (In Portuguese)

61. Malavolta, E.; Vitti, G.C.; Oliveira, S.A. Evaluation of the Nutritional Status of Plants: Principles and Applications, 2nd ed.; Potafos: Piracicaba, Brazil, 1997; 319p. (In Portuguese)

62. Tedesco, M.J.; Gianello, C.; Bissani, C.A.; Bohnen, H.; Volkweiss, S.J. Analysis of Soil, Plants and Other Materials; Universidade Federal do Rio Grande do Sul: Porto Alegre, Brazil, 1995; 174p. (In Portuguese)

63. Fageria, N.K.; Baligar, V.C.; Bailey, B.A. Role of Cover Crops in Improving Soil and Row Crop Productivity. Commun. Soil Sci. Plant Anal. 2005, 36, 2733-2757. [CrossRef]

64. Team, R.C. R: A Language and Environment for Statistical Computing; R Foundation for Statistical Computing: Vienna, Austria, 2018; Available online: http:/ / www.R-project.org/ (accessed on 6 July 2019). 